\title{
An appraisal of geohydrological status and assessment of groundwater quality of Indpur Block, Bankura District, West Bengal, India
}

\author{
Moumita Palmajumder ${ }^{1}$. Susanta Chaudhuri ${ }^{1} \cdot$ Vikas K. Das $^{1} \cdot$ Sisir K. Nag ${ }^{1}$
}

Received: 20 June 2020 / Accepted: 3 March 2021 / Published online: 17 March 2021

(c) The Author(s) 2021

\begin{abstract}
The present work aimed to evaluate the overall hydro-geological status of Indpur block, Bankura district, West Bengal, India. Despite of having adequate annual precipitation, south-western districts of the state of West Bengal, India, are considered to be a significantly water-stressed area of the state. This is because of unfavorable geological setting near to subsurface occurrence of impervious lithology and inundated nature of surface drainage pattern. The study was carried out both in preand post-monsoon seasons of 2019 to obtain an updated current status on concentration and spatiotemporal fluctuations of controlling ions of the subsurface water. Estimation of major physicochemical parameters and specific qualitative chemical characterization of groundwater were rated through field and laboratory studies. Water samples were collected from twentytwo equidistantly scattered tube wells in the block. Seasonal variations of water table elevation heads and subsurface shift of predominant recharge zones of the block were also demarked. Drinking, domestic and irrigation suitability of the block water were measured by the estimation of parameters such as Sodium Adsorption Ratio (SAR), Magnesium Adsorption Ratio (MAR), Soluble Sodium Percentage (SSP), Residual Sodium Carbonate (RSC), Permeability Index (PI), Total Hardness (TH) and Kelly's ratio (KR) and piper trilinear plots. Sustainable non-availability of groundwater seems to be the major problem of the studied area, which intern resulted in overexploitation, mostly for cultivation practices causing considerable depletion of its suitability as drinking and irrigation. Further, results show that suitability of the water both for domestic and irrigation of the studied area may be termed as 'good' to 'moderate' with a few exceptions on a local scale. Judging by every parameter, it can be stated that groundwater of Indpur block is not much suitable for drinking purposes.
\end{abstract}

Keywords Hydrogeological status · Qualitative appraisal · Piper diagram · Indpur · Bankura district

\section{Introduction}

Groundwater is a precious resource of finite extent. Timely and reliable information on the occurrence and movement of groundwater is a prerequisite for meeting its growing demand for drinking, domestic and industrial sector. Assessment of physicochemical attributes of groundwater and hydraulic characteristics of aquifer at regular intervals is essential for proper planning and management of groundwater resources. This need is more crucial for the areas, where the overall geological setting is adverse for

Vikas K. Das

k.d.vikas5@gmail.com

1 Department of Geological Sciences, Jadavpur University, Kolkata 700032, India sustainable storage of infiltrated water despite of adequate annual precipitation. Generally, moving out of groundwater with a considerably higher velocity as base-flow increase the concentration of influencing chemical ions (Domenico and Schwartz 1990; Freeze and Cherry 1979; Kortatsi 2007). Hence, local geomorphology, characteristics of surface soil and its thickness, geological history of aquifers are intercalated sharply with the shortage of availability as well as the suitability of groundwater for its usage towards drinking and irrigation. Assessment of groundwater usually for qualitative purposes is essential. Groundwater quality has been deteriorating over the last few decades due to the massive rise of industries and population. The overexploitation of groundwater is responsible for enhancing the depth of local groundwater table, and this depletion is leading to a severe degradation of water quality (Patil and Patil 2010; Nag and Biswas 2016). Therefore, there is an essential requisite to 
estimate and evaluate the subsurface water status constantly for its optimum usage, availability and accessibility (Reddi et al. 1993; Jeevanandam et al. 2006; Karunakaran et al. 2009; Tyagi et al. 2009; Nagarajan et al. 2010; Prasanna et al. 2011).

Review of literature revealed that investigation on physiochemical appraisal of groundwater suitability for its diverse usages in different areas of the Indian subcontinent was generally confined to a comparatively larger region of a geological terrain; river basin; state or district level (Jeevanandam et al. 2006; Laluraj and Gopinath 2006; Tyagi et al. 2009; Prasanna et al. 2011).

However, to frame a specific water management plan with a proper focus to its sustainable availability and quality, there is a need to evaluate the groundwater scenario more intensely in micro-scale, comprising a concise small administrative area like Sub-division to the Block level (Nag and Ray 2015; Palmajumder et al. 2020). Except a few recent investigations (Chakrabarti and Bhattacharya 2013; Mondal and Kumar 2017; Rudra and Khan 2019) on excess fluoride concentration, overall information on updated hydrogeological status and groundwater quality of Bankura district, west Bengal is scanty. It is the standard practice of the Government to allocate the funds (related to public health engineering) according to the requisites of its administrative units like local 'block development offices', from there to 'municipalities' or village 'panchayats'. Therefore, it is a necessity to focus intensely on the groundwater-related problems in micro-scale rather than broad expanded geological terrain to investigate the minutes of the issues in details for a 'Block' or 'Subdivision' level. Indpur is such a block in the Western part of the district that is traditionally suffering from groundwater-related issues allied to sustainability and overall quality of the groundwater. Therefore, the present study was confined to the Indpur block, Bankura, West Bengal, India to evaluate and appraise the overall groundwater status.

Geologically the location is at the eastern fringe of Chotanagpur plateau, northern extremities of Darakeswar-Kangsabati basin. According to the report of CGWB, out of the 23 blocks of the district, Indpur is one of the peripheral blocks of the district, suffering from periodical water scarcity and degraded water quality (CGWB 2010). The occurrence of crystalline impervious rocks near to the surface and presence of highly permeable lateritic residual meta-sediment improvised an overall adverse geological condition on the sustainability of groundwater. Inundated nature of surface drainage system of the area is one of the prime unfavorable geohydrological conditions for groundwater sustainability. An overall adverse hydrogeological scenario persists on availability and quality of groundwater for a prolonged period.

Pre-monsoon and post-monsoon seasonal fluctuations (hereafter will be referred as PrM and PoM, respectively) of water table head above mean sea level (MSL) was estimated to get an idea on the subsurface flow direction of groundwater and seasonal sift of major recharge zones. Physical parameters at the in-situ condition and chemical analysis to quantify the concentrations of major ions were performed for both the PrM and PoM to evaluate its suitability for drinking, domestic and agricultural purposes. Based on the literature survey, few similar investigations were also carried out by researchers (CGWB 2010; Nag and Lahiri 2012; Nag and Ghosh 2013; Nag and Ray 2015) in different blocks of western districts of West Bengal; however, till now no such intense geohydrological survey exclusively for Indpur block, Bankura District is reported. It is expected that obtained updated output will benefit the irrigation planners, farmers, small-scale industrialist and overall health of the entire community of those blocks.

\section{Study area}

The present geohydrological investigation and physicochemical appraisal of groundwater were constricted in Indpur block of Khatra subdivision, Bankura District, West Bengal, India (Fig. 1). The area is primarily characterized by loosely compacted porous ferruginous soil, beds of laterite and irregular patches of recent alluvium in the western side of the block. Eastern part of the block has a wider plain of recent alluvium. Area of the block is $302.60 \mathrm{sq}$. $\mathrm{km}$ with an average elevation of $138 \mathrm{~m}$.

\section{Geology and soils}

The soil of the area is mainly lateritic, having significantly high porosity and permeability. The south-eastern part of the block consists of a considerably thick pile of recent alluvium and patches of loamy meta-sediments. The northern and northwestern part of the block has profuse occurrence and exposures of near to surface crystalline impervious rocks, mainly amphibolitic and granitic in composition. The basement rocks are frequently fractured and thereby produces high permeability (Acworth 1987; Krishnamurthy et al. 2000; Dewandel et al. 2006). Basal impervious rocks were often associated with closely placed fractures and joints with SSE-NNW trends. The thickness of the overlying lateritic soil cover varies from 0.5 to $6.5 \mathrm{~m}$ and gradually thickens towards the SE side of the block following the geomorphological slope of the area. As there is no specific surface drainage outlet in the block, surface runoff during rainy season flows according to the direction of surface slope towards SE. Comparatively thicker layers of coarse meta-sediment in the $\mathrm{E}$ and SE side of the block serve as a temporal recharge zone during PoM. Overall stagnancy of groundwater is substantially stumpy in the block. 

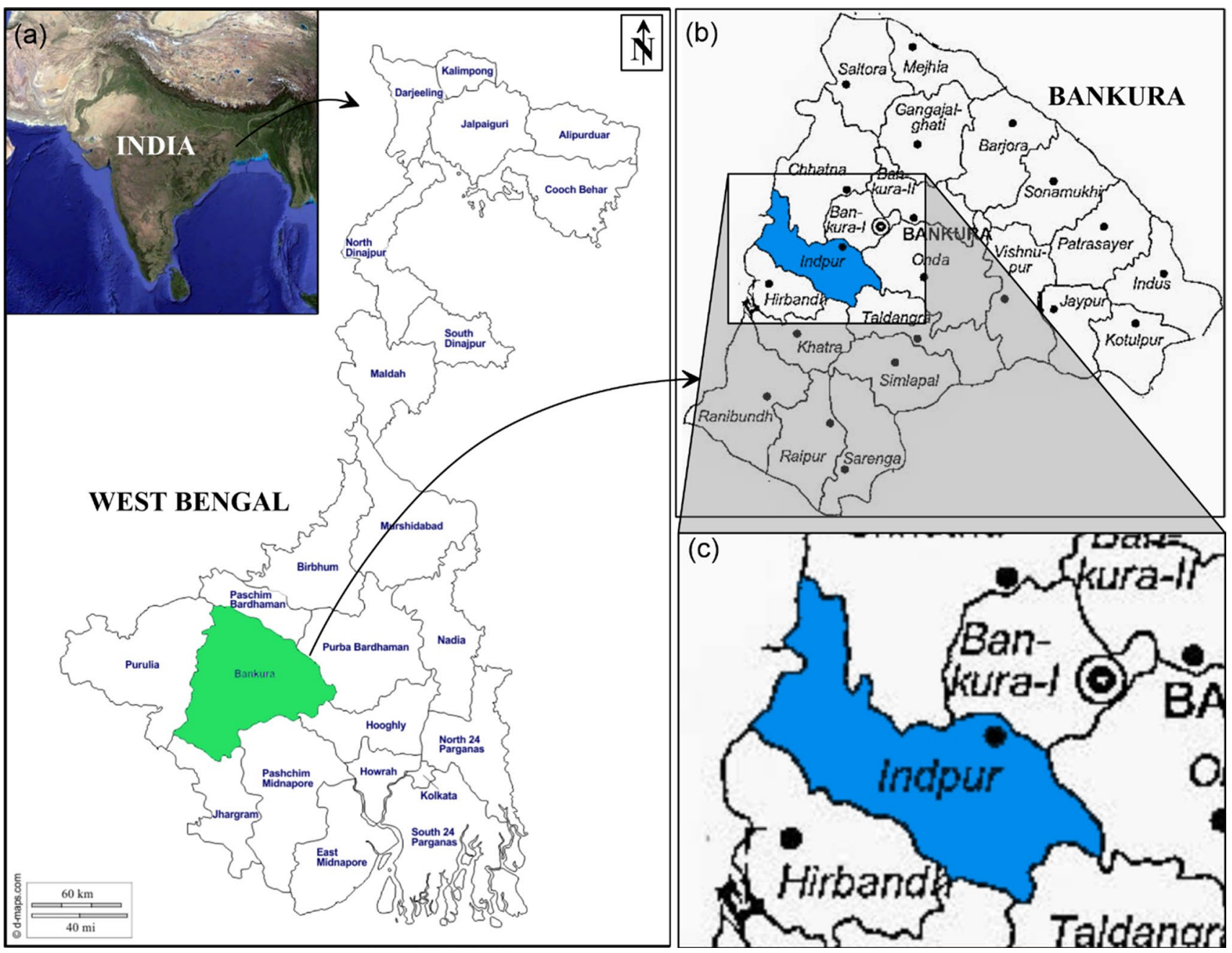

Fig. 1 Study area-Indpur block, Bankura district, West Bengal, India

The annual average rainfall in the District is about $1400 \mathrm{~mm}$ and $80 \%$ of annual precipitation occurs during June to September (CGWD 2015-2016). The Dwarkeshawar, Kangshabati, Silabati and Damodar with their tributaries constitute the main drainage system of the Bankura district. Other important rivers are the Gandheswari, Berai, Sali and Jaiponda. All these rivers originate from the western upland beyond the geographical boundary of the district and flow in south-east direction of the district. Agricultural fields, mainly of paddy and seasonal vegetables, are common occurrence in the eastern side of the block. Feeder canal from Kansabati barrage is the key supply of irrigation water in the block, otherwise manual and mechanical pumping of subsurface water is the common practice to thrive with the cultivation. Cultivation of seasonal vegetables mainly constricted in the SE side of the block. Total irrigated area in Indpur block is 6290 hectares (20.54\% of the block area), out of which 3570 hectares is being served by canal water, 850 hectares by tank water, 1800 hectares by lift irrigation, 40 hectares by open dug wells and 30 hectares by other methods (CGWD 2015-2016).

\section{Materials and methods}

The present study comprised of a collective series of field investigation and analysis of groundwater samples thereafter. The methodology is categorized into three major steps as selection of locations and determination of its geospatial location, instantaneous estimation of some of the major physicochemical parameters in in-situ condition and laboratory chemical analysis of the samples to measure the concentrations of major affecting ions. The groundwater samples were collected during the pre-monsoon season (PrM) and post-monsoon season (PoM) of 2019. Water samples were collected from 22 different locations, located more or less at equal distance. The presence of frequent patches of bushy jungles at the central and the western part of the 
block resulted in inaccessible for sample collection and thus sampling was lesser in numbers in those regions. Figure 2 represents the locations of the sampling wells within the block. The groundwater table depth ( $\mathrm{m}$, below ground level) was measured in all locations by 'Solinst $100 \mathrm{~m}$ Water level indicator' (model 101B) to get location wise elevation head above Mean Sea Level (MSL) of the GWT.

Table 1 represents location-wise altitudes, seasonal fluctuations of water table depth and elevation of groundwater heads. Instantaneous measurements of some major physicochemical parameters like pH, Electrical Conductivity (EC) and Total Dissolved Solids (TDS) of the collected samples were taken by using Hanna portable multi-parameter water testing instrument (model HI98194). The measurement of physical parameters was followed by the chemical analysis to estimate the fluctuation of concentration of major ions following the standard laboratory procedure (APHA 1995), to evaluate the status of overall suitability of groundwater towards health, domestic and irrigation. Parameters like Residual Sodium Carbonate (RSC), Sodium Adsorption Ratio (SAR), Magnesium Absorption Ratio (MAR), Kelly's Ratio (KR), Soluble Sodium Percentage (SSP) and the Total Hardness (TH) were derived, and these values were plotted on standard reference diagrams like Wilcox, U.S. Salinity (US Salinity Lab 1954) and Piper diagrams (Piper 1944), to estimate the suitability for agricultural and drinking purposes. Spatial variation maps of major affecting parameters were done by extracting the studied Block area from TNT MIPS 2017-GIS-based software and was made geo-referenced. After that, parameter-wise contour variation plots with specific frequency were prepared by using 'Golden
Surfer 13' software to get overall visualization of the temporal and spatial fluctuation of groundwater table head, its movement and physicochemical quality.

The suitability of water for irrigation in case of clay soils is determined by the residual sodium carbonate index of water/soil signifying the alkalinity hazard. The quantity of bicarbonate and carbonate in excess of alkaline earths $\left(\mathrm{Ca}^{2+}+\mathrm{Mg}^{2+)}\right.$ also influence the suitability of water for irrigation purposes. When the sum of carbonates and bicarbonates is in excess of calcium and magnesium, there may be possibility of complete precipitation $\mathrm{Ca}$ and $\mathrm{Mg}$ (Raghunath 1987).

$\mathrm{RSC}=\left(\mathrm{HCO}_{3}^{-}+\mathrm{CO}_{3}^{2-}\right)-\left(\mathrm{Ca}^{2+}+\mathrm{Mg}^{2+}\right)$

The sodium adsorption ratio (SAR) is an irrigation water quality parameter used in the management of sodiumaffected soils. It is an indicator of the suitability of water for use in agricultural irrigation, as determined from the concentrations of the main alkaline and earth alkaline cations present in the water. According to Richards LA (US Salinity Laboratory, 1954), the formula for calculating the sodium adsorption ratio (SAR) is:

$\mathrm{SAR}=\frac{\mathrm{Na}^{+}}{\sqrt{\frac{\mathrm{Ca}^{2+}+\mathrm{Mg}^{2+}}{2}}}$

where sodium, calcium and magnesium concentrations are expressed in meq/L.

Groundwater generally maintains a state of equilibrium by controlling the $\mathrm{Mg}^{2+}$ and $\mathrm{Ca}^{2+}$ concentration in it (Hem
Fig. 2 Locations of the sampling wells within the block

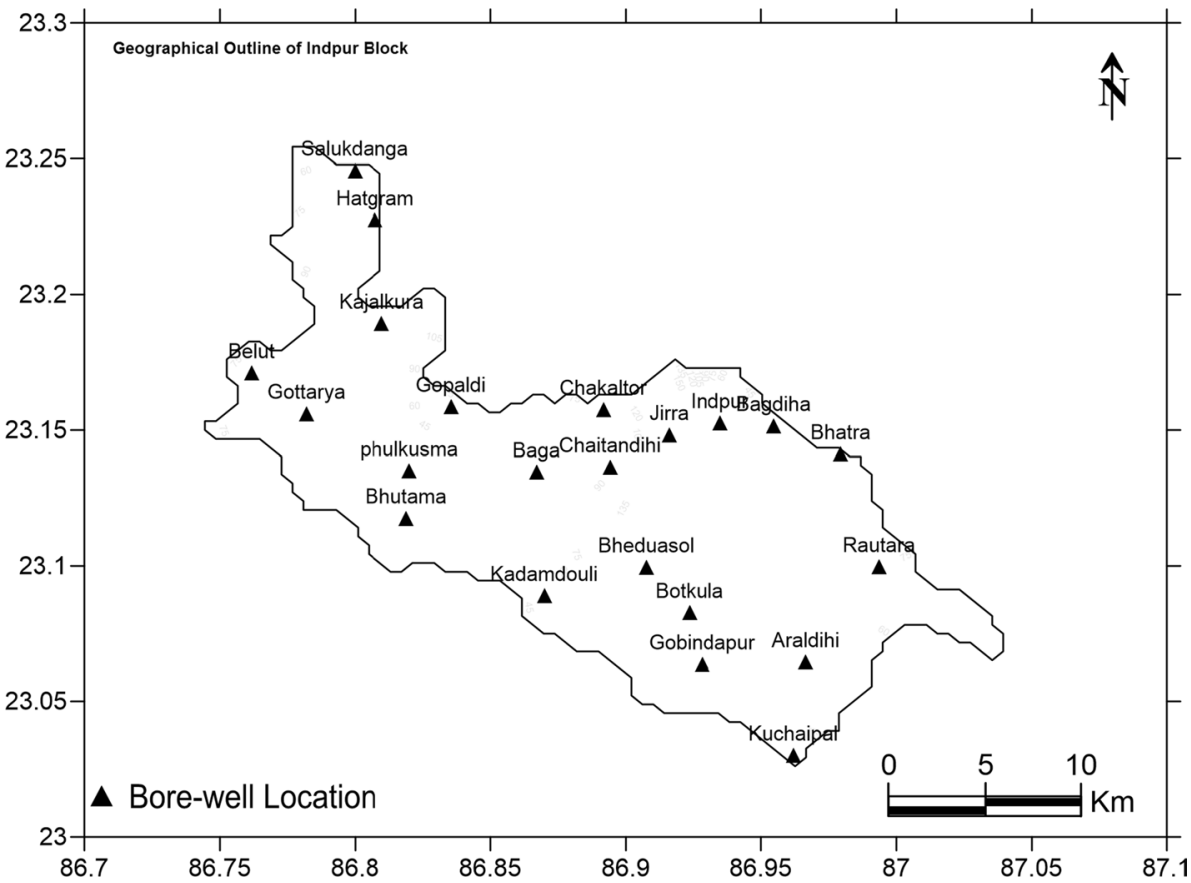

年

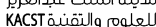


Table 1 Seasonal fluctuations of water table depth and head of the studied locations

\begin{tabular}{|c|c|c|c|c|c|c|}
\hline \multirow[t]{2}{*}{ Location no. } & \multirow[t]{2}{*}{ Location name } & \multirow[t]{2}{*}{$\begin{array}{l}\text { Altitude }(\mathrm{m}) \\
\text { above MSL }\end{array}$} & \multicolumn{2}{|c|}{$\begin{array}{l}\text { Water table depth (m, } \\
\text { bgl) }\end{array}$} & \multicolumn{2}{|c|}{$\begin{array}{l}\text { Water table head } \\
\text { (m) above MSL }\end{array}$} \\
\hline & & & PrM & PoM & PrM & PoM \\
\hline L1 & Hatgram & 150 & 29.9 & 5.6 & 120.1 & 139.9 \\
\hline L2 & Salukdanga & 144 & 26.9 & 5.6 & 117.1 & 138.5 \\
\hline L3 & Kajalkura & 159 & 2.9 & 5.7 & 156.1 & 153.3 \\
\hline $\mathrm{L} 4$ & Belut & 175 & 7.3 & 5.7 & 167.7 & 169.3 \\
\hline L5 & Gottarya & 174 & 6.9 & 5.6 & 167.2 & 168.4 \\
\hline L6 & Gopaldi & 173 & 3.4 & 5.2 & 169.6 & 167.9 \\
\hline L7 & Phulkusma & 165 & 9.2 & 4.6 & 155.8 & 160.4 \\
\hline L8 & Bhutama & 162 & 4.9 & 6.3 & 157.2 & 155.7 \\
\hline L9 & Kadamdouli & 128 & 13.6 & 4.7 & 114.5 & 123.3 \\
\hline L10 & Chaitandihi & 144 & 6.4 & 5.2 & 137.6 & 138.9 \\
\hline L11 & Baga & 154 & 19.8 & 5.7 & 134.2 & 148.3 \\
\hline L12 & Chakaltor & 149 & 1.4 & 5.6 & 147.7 & 143.4 \\
\hline L13 & Jirra & 159 & 24.1 & 4.4 & 134.9 & 154.6 \\
\hline L14 & Bagdiha & 142 & 6.3 & 3.5 & 135.8 & 138.6 \\
\hline L15 & Indpur & 136 & 2.0 & 3.0 & 134.0 & 132.9 \\
\hline L16 & Bhatra & 132 & 5.1 & 3.5 & 126.9 & 128.5 \\
\hline L17 & Rautara & 111 & 4.1 & 3.8 & 106.9 & 107.2 \\
\hline L18 & Araldihi & 125 & 8.6 & 4.2 & 116.4 & 120.8 \\
\hline L19 & Kuchaipal & 114 & 16.8 & 4.3 & 97.3 & 109.7 \\
\hline L20 & Gobindapur & 114 & 3.4 & 5.1 & 110.6 & 108.9 \\
\hline L21 & Botkula & 136 & 8.5 & 5.1 & 127.6 & 130.9 \\
\hline L22 & Bheduasol & 141 & 7.4 & 5.3 & 133.6 & 135.7 \\
\hline Average & & 144.9 & 9.9 & 4.9 & 134.9 & 139.8 \\
\hline Maximum & & 175.0 & 29.9 & 6.3 & 169.6 & 169.3 \\
\hline Minimum & & 111.0 & 1.4 & 3.0 & 97.3 & 107.2 \\
\hline
\end{tabular}

1985). However, the alkalinity of the soil increases if more $\mathrm{Mg}^{2+}$ in groundwater is introduced during equilibrium, adversely affects the soil quality which result in decrease of crop yield (Kumar et al. 2007). Magnesium adsorption ratio (MAR) is commonly used for calculating the magnesium hazard index (Paliwal 1972) using the formula:

MAR $=\left(\mathrm{Mg}^{2+} \times 100\right) /\left(\mathrm{Ca}^{2+}+\mathrm{Mg}^{2+}\right)$

Among the soluble constituents of irrigation water, sodium is considered the most hazardous. Excess of sodium ions characterizes the water as saline or alkaline depending upon its occurrence in association with chloride/sulphate or carbonate/bicarbonate ions. The quality of irrigation water used to be evaluated with respect to sodium based on soluble sodium percentage (SSP) calculated as below (Todd 1980).

$\mathrm{SSP}=\frac{\left(\mathrm{Na}^{+}+\mathrm{K}^{+}\right) \times 100}{\left(\mathrm{Ca}^{2+}+\mathrm{Mg}^{2+}+\mathrm{Na}^{+}+\mathrm{K}^{+}\right)}$

To measure sodium ion concentration against calcium and magnesium ion concentrations Kelly's Ratio (Kelly 1963) is used:
$\mathrm{KR}=\mathrm{Na}^{+} /\left(\mathrm{Ca}^{2+}+\mathrm{Mg}^{2+}\right)$

The presence of calcium carbonate leads to temporary hardness and gets removed when water is boiled, whereas the presence of $\mathrm{Ca}^{2+}$ and $\mathrm{Mg}^{2+}$ causes permanent hardness which gets removed by only ion exchange processes. The total hardness (TH) is determined by the following equation:

$\mathrm{TH}(\mathrm{mg} / \mathrm{L})=2.497 \mathrm{Ca}^{2+}+4.115 \mathrm{Mg}^{2+}$

where concentrations of all ions in the mentioned equations (Equation 1-6) are in in meq/L.

\section{Results and discussion}

Table 1 represents the names of studied locations from where water samples were collected. It also reveals the altitudes and seasonal fluctuation of groundwater table elevation heads location. This provided the present status on the directional movement to locate potential recharge and discharge zone of the block for PrM and PoM sessions. 


\section{Water table depth and seasonal shifts}

Figure $3 a, b$ portrays the fluctuation contours of subsurface water table elevation head in meter above mean sea level (MSL). From the map, it is revealed that water table head was comparatively much higher at the western (W) and northwestern (NW) side of the block during the PrM season. The maximum height of the water table head is observed at Gopaldi (169.6 m, L6) located at the Western part of the block during PrM season. Moreover, during PoM the maximum height of the water table head was observed at Belut (169.3 m, L4), this gradually descended towards the E to SE part of the block (Table 1). It is also noted from the plots that the area of higher head (of $162 \mathrm{~m}$ to $>168 \mathrm{~m}$ ) expanded over a substantial area during PoM at the extreme NW side of the block, as revealed by the uplift of heads at Hatgram (L1) and Salukdanga (L2) during PoM. Sequentially lowering of head expanded in the extreme SE of the block and indicates a steady flow of subsurface water towards that direction during PoM.

The minimum head was noted $97.3 \mathrm{~m}$ at Kuchaipal (L19) during PrM and at Rautara (L17) during PoM (107.2). Figure $4 a, b$ represents the vector plot of subsurface water movement (as worked out using the Surfer) which shows the flow is towards E to SE corner of the block. The overall flow direction was towards SE from the W side of the block. Stagnancy of groundwater flow was observed for both the season at the south of the central portion and south-eastern region of the block.

It is pertinent from Fig. $4 \mathrm{a}, \mathrm{b}$ that two major discharge zones have been formed due to the convergence of the vector plot at the central region of the block. This discharge (a) Pre-monsoon

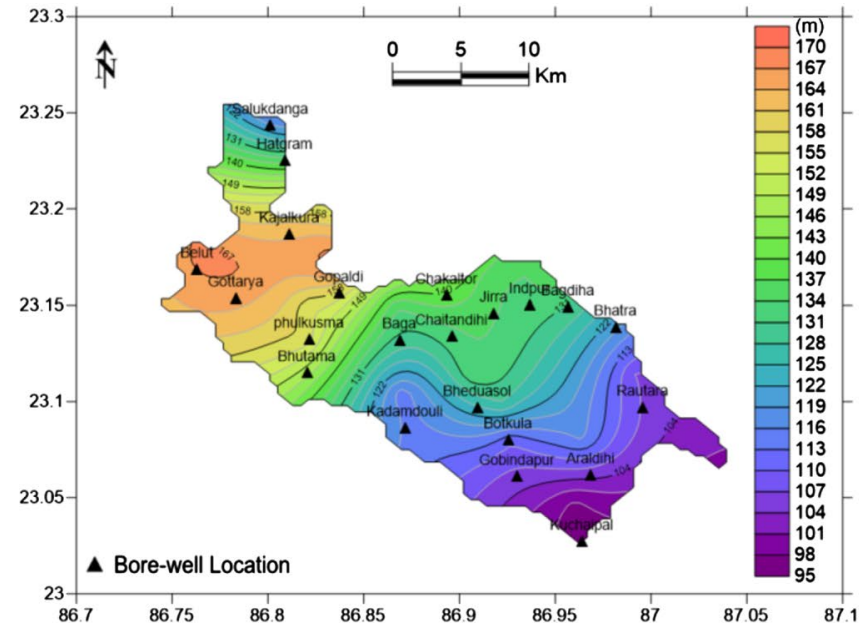

(b) Post-monsoon

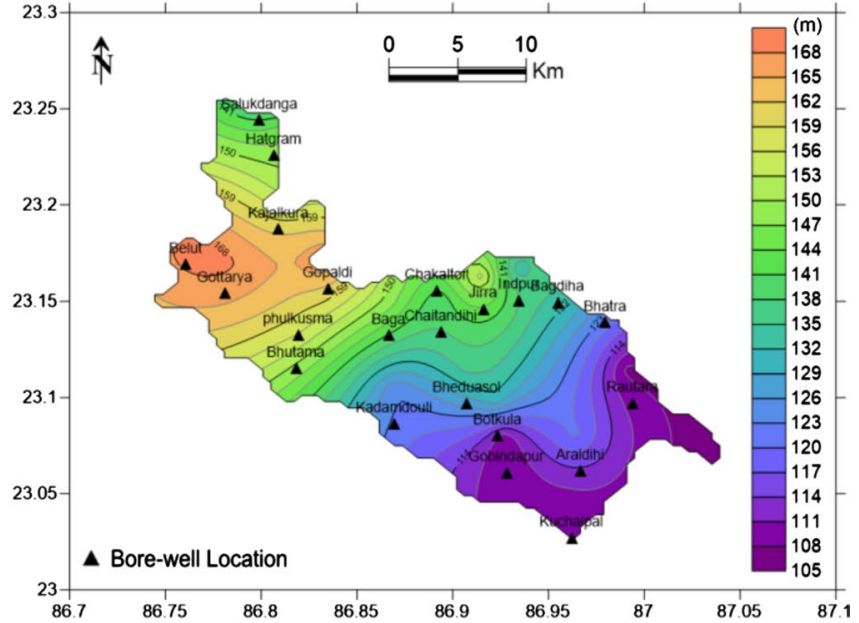

Fig. 3 Spatial fluctuation of groundwater table head (MASL) for a PrM; b PoM
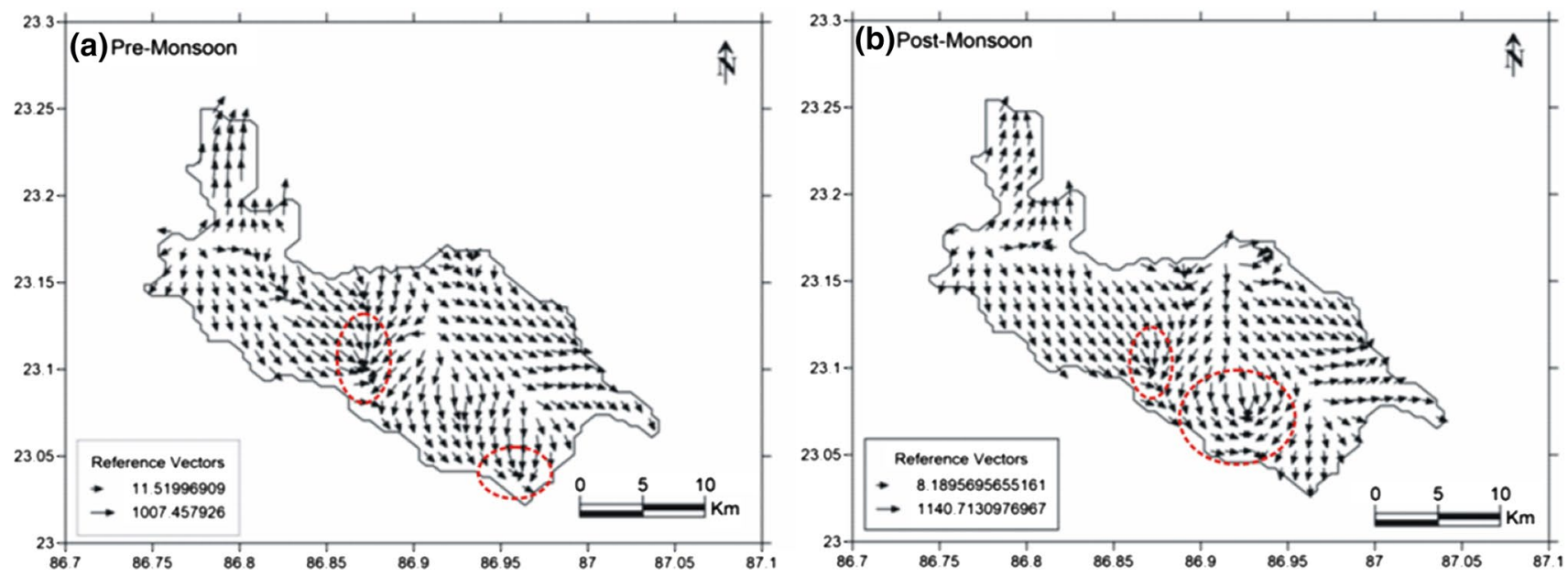

Fig. 4 Vector plot showing groundwater flow directions and shift of recharge zones during a PrM; b PoM 
zones were observed for both PrM and PoM seasons. This discharge zones were observed between the longitudes of 86.85-86.90 (Fig. 4a, b which falls within the Baga, Kadamdouli and Bheduasol (Fig. 2). However, the few samples were collected between the longitudes of 86.80-86.85 where the vector plots show a SE trends and converges between the longitudes of 86.85-86.90 (Fig. 4a, b).

Further study and comparison of the plots (Fig. 4a, b) reveal that there is a sharp uplift of impervious basement rock at the extreme NW side of the block which acted as a subsurface flow divider that diverted the groundwater flow in two almost opposite directions at north and south to SE, respectively (from locations L3, L4, L5 and L6). These diversions of flow were more enhanced during PoM. A similar type of flow divergence was also noticed at the central location of the block (L13; L15; L22). The SE recharge zone expanded inward to a considerable extent during PoM. Enhancement of surface run-off during PoM with rapidness of interflow through thin soil cover, near to surface occurrence of impervious basement rock within this area could possibly be the key reason for this migration of recharge zone towards SE. Furthermore, frequent presences of patches of bushy jungles having negligible inhabitation and practically no irrigation at the central area of the block were seemed to be the prime reasons of that area to evolve as a prospective zone for recharge and stagnancy of groundwater.

\section{Physicochemical parameters measured in situ}

Table 2 presents the major physicochemical parameters measured in the field. The physical parameters measured instantaneously include $\mathrm{pH}, \mathrm{EC}$, TDS with TA and TH.

\section{Variations of pH}

Figure 5a, $\mathrm{b}$ shows the contour plots for $\mathrm{pH}$ variation during PrM and PoM seasons. The limits of $\mathrm{pH}$ ranged between 5.8 and 7 with a mean of 6.6 during PrM, whereas during PoM the range was between 6.3 and 7.0 with a mean $\mathrm{pH}$ of 6.7. The maximum value of $\mathrm{pH}$ was recorded at Gobindaur (L20) and Kadamdauli (L9), situated at the south-eastern corner of the block during both sessions. Further, the minimum
Table 2 Variations of major physicochemical parameters during pre- and post-monsoon

\begin{tabular}{|c|c|c|c|c|c|c|c|c|c|c|c|}
\hline \multirow[t]{2}{*}{ Loc no. } & \multirow[t]{2}{*}{ Location name } & \multicolumn{2}{|l|}{$\mathrm{pH}$} & \multicolumn{2}{|c|}{ TDS (ppm) } & \multicolumn{2}{|c|}{$\mathrm{EC}(\mathrm{mS} / \mathrm{cm})$} & \multicolumn{2}{|c|}{$\mathrm{TA}(\mathrm{mg} / \mathrm{l})$} & \multicolumn{2}{|c|}{ TH (mg/l) } \\
\hline & & PrM & PoM & PrM & PoM & PrM & PoM & PrM & PoM & PrM & PoM \\
\hline 1 & Hatgram & 6.7 & 6.9 & 660 & 180 & 1317 & 365 & 240 & 277 & 443 & 100 \\
\hline 2 & Salukdanga & 6.6 & 7.0 & 513 & 165 & 1022 & 280 & 310 & 285 & 347 & 70 \\
\hline 3 & Kajalkura & 6.8 & 6.9 & 447 & 190 & 895 & 381 & 270 & 260 & 412 & 128 \\
\hline 4 & Belut & 6.8 & 6.7 & 396 & 294 & 791 & 585 & 230 & 230 & 341 & 250 \\
\hline 5 & Gottarya & 5.9 & 6.6 & 810 & 360 & 1621 & 752 & 220 & 223 & 685 & 325 \\
\hline 6 & Gopaldi & 6.4 & 6.5 & 380 & 490 & 762 & 1000 & 170 & 235 & 360 & 400 \\
\hline 7 & Phulkusma & 6.5 & 6.5 & 398 & 398 & 553 & 796 & 120 & 200 & 300 & 312 \\
\hline 8 & Bhutama & 6.1 & 6.4 & 203 & 676 & 408 & 1350 & 130 & 250 & 187 & 636 \\
\hline 9 & Kadamdouli & 7.0 & 7.0 & 242 & 367 & 483 & 733 & 250 & 340 & 239 & 316 \\
\hline 10 & Chaitandihi & 6.5 & 6.6 & 137 & 1270 & 274 & 2520 & 130 & 330 & 119 & 110 \\
\hline 11 & Baga & 6.3 & 6.3 & 786 & 786 & 1753 & 1564 & 70 & 250 & 292 & 600 \\
\hline 12 & Chakaltor & 6.0 & 6.7 & 589 & 778 & 1177 & 1555 & 230 & 450 & 492 & 640 \\
\hline 13 & Jirra & 5.8 & 6.7 & 731 & 1010 & 1460 & 2020 & 250 & 350 & 698 & 925 \\
\hline 14 & Bagdiha & 6.1 & 6.8 & 136 & 620 & 271 & 1240 & 130 & 325 & 109 & 600 \\
\hline 15 & Indpur & 6.9 & 6.9 & 346 & 346 & 682 & 696 & 120 & 360 & 300 & 376 \\
\hline 16 & Bhatra & 6.9 & 6.8 & 352 & 670 & 703 & 1300 & 260 & 306 & 133 & 590 \\
\hline 17 & Rautara & 6.9 & 6.7 & 275 & 790 & 550 & 565 & 240 & 272 & 388 & 650 \\
\hline 18 & Araldihi & 6.6 & 6.6 & 240 & 880 & 479 & 1798 & 180 & 244 & 187 & 690 \\
\hline 19 & Kuchaipal & 6.9 & 6.4 & 179 & 987 & 356 & 1965 & 140 & 240 & 189 & 728 \\
\hline 20 & Gobindapur & 7.0 & 7.0 & 380 & 380 & 776 & 57 & 110 & 210 & 312 & 360 \\
\hline 21 & Botkula & 6.9 & 6.9 & 275 & 425 & 549 & 920 & 230 & 215 & 219 & 400 \\
\hline 22 & Bheduasol & 6.5 & 6.5 & 1843 & 1849 & 3921 & 3684 & 110 & 310 & 720 & 1596 \\
\hline Mean & & 6.6 & 6.7 & 469 & 632.3 & 945.6 & 1187.5 & 188.2 & 280.1 & 339.6 & 491 \\
\hline Maximum & & 7.0 & 7.0 & 1843 & 1849 & 3921 & 3684 & 310 & 450 & 720 & 1596 \\
\hline Minimum & & 5.8 & 6.3 & 136 & 165 & 271 & 57 & 70 & 200 & 109 & 70 \\
\hline
\end{tabular}

$T D S$ total dissolve solids, $E C$ electrical conductance, $T A$ total alkalinity, $T H$ total hardness 
(a) Pre-monsoon

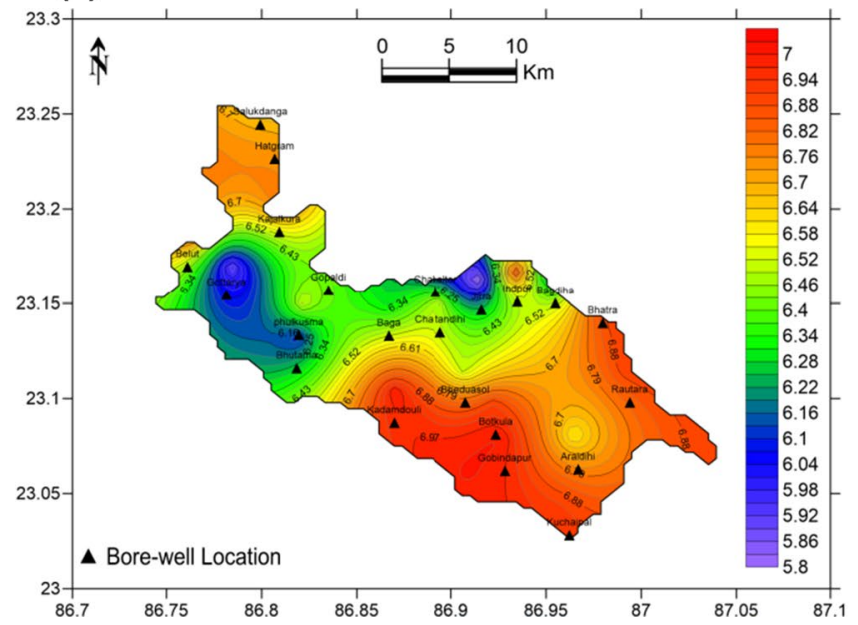

Fig. 5 Spatial distribution of $\mathrm{pH}$ a PrM; b PoM

$\mathrm{pH}$ value, i.e. 5.8 is observed at Jirra (L13) during PrM and 6.3 during PoM at Baga (L11), situated at the North-eastern to central region of the block. From Fig. 5, it is inferred that during PrM, the eastern region of the blocks showed $\mathrm{pH}$ value ranging from 6.7 to 7 which indicates water to be neutral in nature. However, the acidity of the water increased slightly towards the central to western region of the block, where the lowering of $\mathrm{pH}$ was mostly constricted during PoM. Temporal stagnancy of groundwater at central area and SE corner of the block during both the seasons (PrM and PoM) may be the key reason of low values of $\mathrm{pH}$ in those locations. The $\mathrm{pH}$ of the groundwater of the block is close to the standard with the mean value ranging between 6.6 and 6.7, which implies that the water is feebly acidic in nature throughout the year.

(a) Pre-monsoon

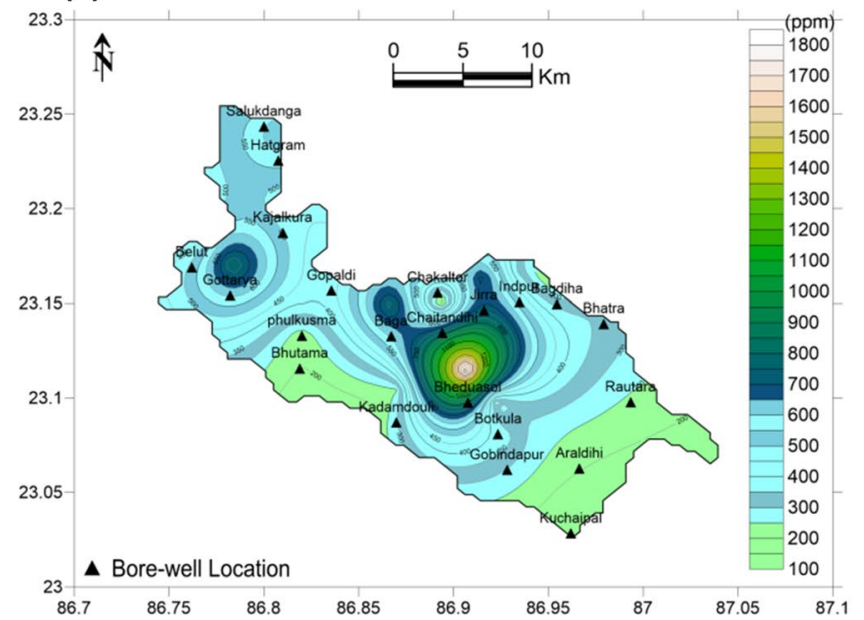

(b) Post-monsoon

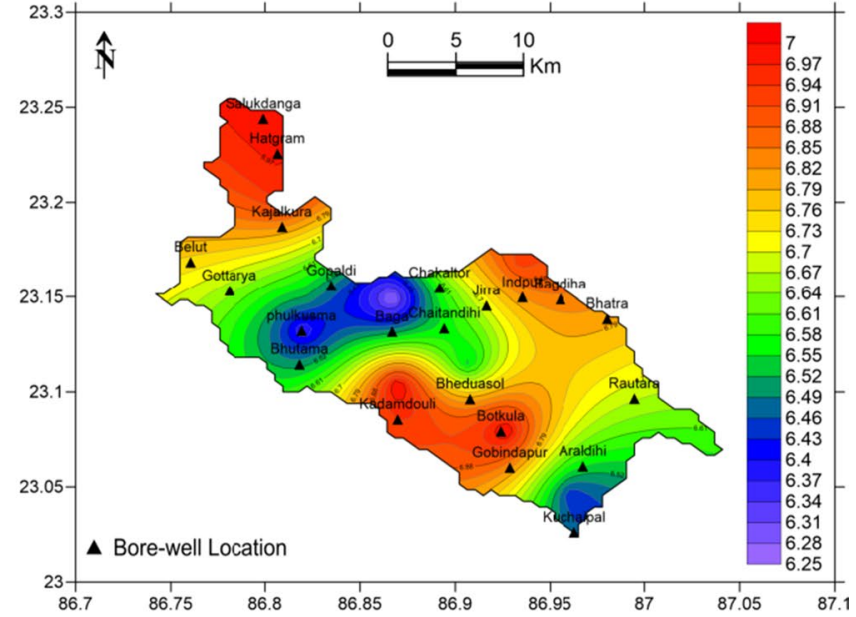

\section{Total dissolved solids (TDS)}

Figure $6 \mathrm{a}, \mathrm{b}$ represents the spatial variation plots of TDS during PrM and PoM. There is a close similarity of overall variation of TDS plot for PrM and PoM with the EC values (Table 2). The mean of TDS is 469 and 632.3 ppm during PrM and PoM, respectively (Table 2). From the spatial plots, it is clear that TDS was comparatively low for the water of Western fringe of the block and increases gradually towards the Central to South-eastern zone, having a close parity with the movement of the subsurface water flow. Further, except a few locations at the western side of the block (L1; L2; L3; L4 and L5), the value of TDS increased substantially during PoM than PrM in the whole block (Fig. 4). Though, as a whole the ranges are within the permissible limits of 'Fresh

(b) Post-monsoon

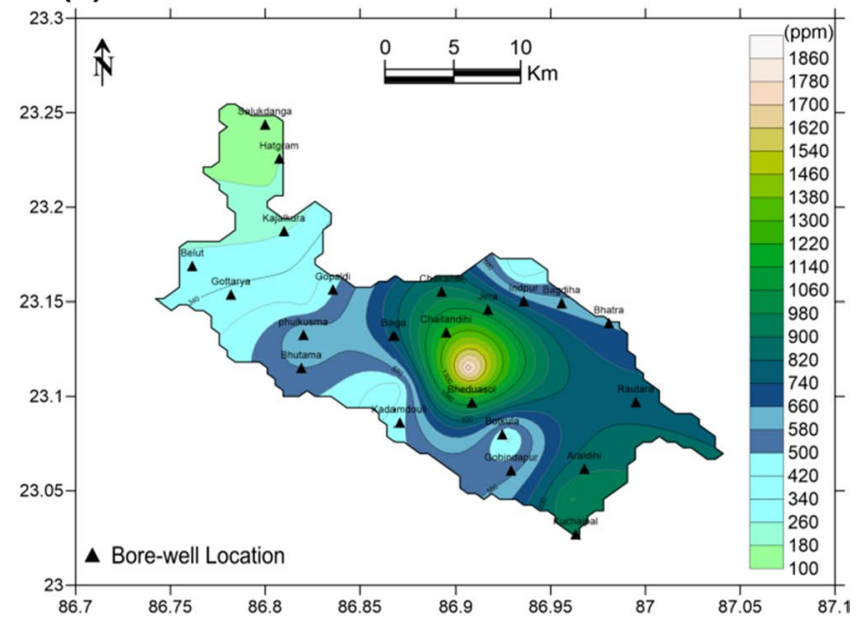

Fig. 6 Spatial variation of TDS a PrM; b PoM 
Water' category (TDS $<1000$, as per WHO 2017), except the location of Bheduasol (L22).

\section{Chemical parameters}

Table 3 presents the concentration and seasonal variations of major ions of the water samples measured in the laboratory following standard procedures. The chemical concentrations were measured for the ions like calcium $\left(\mathrm{Ca}^{2+}\right)$, magnesium $\left(\mathrm{Mg}^{2+}\right)$, chlorine $\left(\mathrm{Cl}^{-}\right)$, nitrate $\left(\mathrm{NO}_{3}{ }^{-}\right)$, sodium $\left(\mathrm{Na}^{+}\right)$, sulphate $\left(\mathrm{SO}_{4}{ }^{2-}\right)$, potassium $\left(\mathrm{K}^{+}\right)$, iron $\left(\mathrm{Fe}^{2+}\right)$ and bi-carbonate $\left(\mathrm{HCO}_{3}^{-}\right)$.

Table 4 reveals a comparative analysis of estimated ranges of concentrations of the major controlling ions of the blockwater with that of the reference acceptable and permissible ranges according to the BIS guideline (IS 10500:2012) for safe drinking purpose. It is pertinent from the comparison (Table 4 ) that almost for all the locations ( $>80 \%$ of locations) concentrations of $\mathrm{NO}_{3}{ }^{-}, \mathrm{Fe}^{2+}, \mathrm{HCO}_{3}{ }^{-}$and $\mathrm{TH}$ values of the groundwater are considerably higher than the acceptable limits for both the seasons (PrM and PoM).

Figure $7 \mathrm{a}, \mathrm{b}$ shows the plots for fluctuation contours of nitrate $\left(\mathrm{NO}_{3}{ }^{-}\right)$concentration. The concentrations range from $2.2 \mathrm{mg} / \mathrm{l} \mathrm{Kadamdauli}$ (L9) to $60.9 \mathrm{mg} / \mathrm{l}$ Jirra (L13), during PrM, with an average of $17.4 \mathrm{mg} / \mathrm{l}$. The range of Nitrate $\left(\mathrm{NO}^{3-}\right)$ concentrations increased considerably during PoM from $27.2 \mathrm{mg} / \mathrm{l}$ at Belut (L4) to $620.6 \mathrm{mg} / \mathrm{l}$ at Kuchaipal (L19) with an average of $155.9 \mathrm{mg} / \mathrm{l}$. From the maps, it is pertinent that for the entire studied area the concentration of $\mathrm{NO}_{3}{ }^{-}$exceeds rapidly in PoM for almost entire block and radically superseded the maximum desirable limit of $50 \mathrm{mg} / \mathrm{l}$ (WHO 2017).

Mean concentration of $\mathrm{NO}_{3}{ }^{-}$for the block ranged from $17.4 \mathrm{mg} / \mathrm{l}(\mathrm{PrM})$ to $155.9 \mathrm{mg} / \mathrm{l}(\mathrm{PoM})$. Zones of the highest concentration of $\mathrm{NO}_{3}{ }^{-}$, during PoM (Fig. 7b) covered a sizable area at the E and SE corner of the block. Out of 22 studied locations, 17 locations showed a considerably higher concentration of $\mathrm{NO}_{3}{ }^{-}$above its maximum permissible range of $>50 \mathrm{mg} / \mathrm{l}$ (WHO 2017). Seasonal availability of groundwater during PoM improvises the cultivation practices and thereby enhanced use of fertilizers. This random use of chemical fertilizers is a reasonable cause for this higher concentration of $\mathrm{NO}_{3}{ }^{-}$during PoM. A high concentration of nitrogen, as nitrate, in drinking water can be harmful to young infants or young livestock (Sajil Kumar et al. 2014). According to Rajmohan and Elango (2005), in the agricultural areas, increased groundwater level generally noticed during post-monsoon period, which causes increase in the leaching of nitrate through 'vadose zones' and rise in the nitrate concentration. Increased use of fertilizer during agricultural practices was also a significant reason for increased concentration of $\mathrm{NO}_{3}^{-}$in groundwater (Babiker et al. 2004; Nas and Berktay 2006; Widory et al. 2004) at the central part and eastern side of the block.

Figure $8 \mathrm{a}, \mathrm{b}$ shows the fluctuations of iron $\left(\mathrm{Fe}^{2+}\right)$ concentration and reveals a wide range of variation from $0.2 \mathrm{mg} / \mathrm{l}$ at Kadamdouli (L9) to $45.2 \mathrm{mg} / \mathrm{l}$ at Hatgram (L1). Mean concentration of $\mathrm{Fe}^{2+}$ in the block water is significantly high during PrM (5.1 mg/l) than PoM (0.9 mg/l). For majority of the studied locations, the concentration of $\mathrm{Fe}^{2+}$ is higher than its highest acceptable limits $0.3 \mathrm{mg} / \mathrm{l}$ (IS 10500:2012) and $0.1 \mathrm{mg} / \mathrm{l}$ of WHO (2017), respectively.

From the spatial plots, it can be inferred that the average concentration of $\mathrm{Fe}^{2+}$ exceeds its limit throughout the entire block during PrM (Fig. 8a), in contrast the southern zone of central part of the block seems to be crucial for increased concentration of $\mathrm{Fe}^{2+}$ during PoM. Increased leaching through the comparative thicker layers of residual lateritic soil cover after PoM is the crucial reason for the rapid increase in Fe during PrM in almost all the locations. Excessive iron in water is a widespread threat to human health and responsible for severe stomach problems, nausea, vomiting, skin disease (Widory et al. 2004).

Some of the areas at the extreme south of the district were reported high fluoride $\left(\mathrm{F}^{-}\right)$concentration than highest permissible limit of $1.5 \mathrm{mg} / \mathrm{l}$, in the past (Chakrabarti and Bhattacharya 2013). Concentrations of fluoride $\left(\mathrm{F}^{-}\right)$were tested for all the collected samples. However, the concentration of the fluoride in the studied water were observed to be negligible and no sample exceeded the permissible limit based on WHO (2017) during both PrM and PoM sessions (Table 2). Thus, $\mathrm{F}^{-}$concentration in the studied area is considered not to be harmful for irrigation and domestic uses. Table 2 reveals a comparative analysis of estimated ranges of concentrations of the major controlling ions of the blockwater with that of the reference acceptable and permissible ranges according to the WHO (2017) and BIS guideline (IS 10500:2012) for safe drinking purpose.

\section{Appraisal of water quality for irrigation and domestic use}

The suitability of the water for irrigation is dependent on its mineral constituents. In fact, salts can be highly harmful and effect the plant growth physically, by restricting the intake of water by modifying the osmotic processes (Twari et al. 2016). Salinity, sodicity and toxicity generally considered for evaluation of the suitability of water for irrigation (Shainberg and Oster 1976; Todd 1980). Parameters like Sodium Absorption Ratio (SAR), Magnesium Absorption ratio (MAR) Soluble Sodium Percentage (SSP), Permeability Index (PI), Residual Sodium Carbonate (RSC), Permeability Index (PI) and Kelly's Ratio (KI) were computed to evaluate the irrigation suitability of water, both for PrM

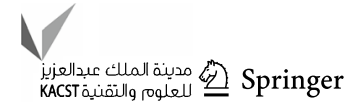


Table 3 Concentrations and seasonal variations of major ions in the water samples of the studied block

\begin{tabular}{|c|c|c|c|c|c|c|c|c|c|c|c|c|c|}
\hline \multirow[t]{2}{*}{ Loc no. } & \multirow[t]{2}{*}{ Location name } & \multicolumn{2}{|c|}{$\begin{array}{l}\mathrm{HCO}_{3}^{-} \\
(\mathrm{mg} / \mathrm{l})\end{array}$} & \multicolumn{2}{|l|}{$\begin{array}{l}\mathrm{Cl}^{-} \\
(\mathrm{mg} / \mathrm{l})\end{array}$} & \multicolumn{2}{|l|}{$\begin{array}{l}\mathrm{SO}_{4}{ }^{2-} \\
(\mathrm{mg} / \mathrm{l})\end{array}$} & \multicolumn{2}{|c|}{$\begin{array}{l}\mathrm{NO}_{3}^{-} \\
(\mathrm{mg} / \mathrm{l})\end{array}$} & \multicolumn{2}{|c|}{$\begin{array}{l}\mathrm{Na}^{+} \\
(\mathrm{mg} / \mathrm{l})\end{array}$} & \multicolumn{2}{|c|}{$\begin{array}{l}\mathrm{Mg}^{2+} \\
(\mathrm{mg} / \mathrm{l})\end{array}$} \\
\hline & & PrM & PoM & PrM & PoM & PrM & PoM & PrM & PoM & PrM & PoM & PrM & PoM \\
\hline 1 & Hatgram & 240.9 & 340.7 & 184.3 & 50.2 & 23.3 & 80.5 & 26.1 & 55 & 96.8 & 27.3 & 44.5 & 8.5 \\
\hline 2 & Salukdanga & 310.7 & 350.3 & 85.1 & 46.7 & 23.6 & 70.2 & 42.9 & 48.8 & 74.6 & 27.4 & 62.2 & 10.1 \\
\hline 3 & Kajalkura & 270 & 317.2 & 113.4 & 55.1 & 25.4 & 75.4 & 53.9 & 49.5 & 34.5 & 28 & 32.3 & 9.7 \\
\hline 4 & Belut & 230.4 & 280.9 & 99.3 & 142.6 & 48.5 & 95.7 & 13.7 & 27.2 & 29.0 & 24.6 & 39.1 & 31 \\
\hline 5 & Gottarya & 220.1 & 275.1 & 248.2 & 184.9 & 50.4 & 160.6 & 22.5 & 36.7 & 30.6 & 24.8 & 94 & 38.2 \\
\hline 6 & Gopaldi & 170.2 & 285.3 & 148.9 & 229 & 14.8 & 395.9 & 5.3 & 146.1 & 23.1 & 26.8 & 27.7 & 29.9 \\
\hline 7 & Phulkusma & 146.4 & 244.5 & 219.9 & 25.2 & 9.9 & 298.4 & 5.2 & 82.6 & 35.9 & 28.7 & 57.6 & 27.9 \\
\hline 8 & Bhutama & 130.9 & 305.6 & 63.8 & 345.4 & 84.6 & 319.2 & 5.3 & 48.3 & 12.9 & 25.2 & 10.5 & 78.3 \\
\hline 9 & Kadamdouli & 250.8 & 414.8 & 21.3 & 110.1 & 142 & 379.3 & 2.2 & 44.3 & 13.5 & 12.1 & 30.1 & 23.8 \\
\hline 10 & Chaitandihi & 130.4 & 405 & 14.2 & 354.3 & 59.3 & 1050 & 19.8 & 138 & 12.9 & 50.8 & 9.2 & 95.5 \\
\hline 11 & Baga & 85.4 & 305.9 & 279.9 & 345.4 & 10.6 & 626.4 & 7.8 & 276.5 & 25.6 & 26.9 & 41.5 & 31.6 \\
\hline 12 & Chakaltor & 230.2 & 549.7 & 163.1 & 230.3 & 23.4 & 803.4 & 11.9 & 250.6 & 38.9 & 39.4 & 42.3 & 50.6 \\
\hline 13 & Jirra & 250.6 & 430.1 & 262.3 & 280.1 & 41.2 & 790.4 & 60.9 & 110.4 & 28.7 & 49.2 & 49.8 & 86.4 \\
\hline 14 & Bagdiha & 130.1 & 400.8 & 28.4 & 192.9 & 24.5 & 420.8 & 23.6 & 115.9 & 17.7 & 38.6 & 7.1 & 54.8 \\
\hline 15 & Indpur & 146.4 & 439.2 & 399.9 & 120.1 & 22.6 & 221.9 & 37.5 & 41.9 & 43.8 & 33.5 & 36.3 & 41.5 \\
\hline 16 & Bhatra & 260.9 & 375.6 & 63.8 & 216.5 & 20.2 & 440.2 & 4.9 & 191.7 & 47.8 & 35.5 & 54.7 & 48.2 \\
\hline 17 & Rautara & 240.8 & 332.5 & 56.7 & 290.2 & 23.1 & 535.3 & 2.7 & 380.5 & 19.2 & 29.8 & 42.3 & 40.7 \\
\hline 18 & Araldihi & 180 & 295.4 & 56.7 & 352.8 & 32.9 & 620.9 & 7.5 & 500.4 & 20.9 & 23.2 & 18.2 & 32.1 \\
\hline 19 & Kuchaipal & 140.5 & 292.8 & 42.5 & 415.5 & 45.3 & 684.3 & 7.9 & 620.6 & 21.6 & 20 & 19.2 & 26.9 \\
\hline 20 & Gobindapur & 134.2 & 256.2 & 479.9 & 100.1 & 33.7 & 210.9 & 5.8 & 84.1 & 35.3 & 21.5 & 56.7 & 36.6 \\
\hline 21 & Botkula & 230.5 & 260 & 28.4 & 128 & 41.7 & 240.4 & 7.1 & 100 & 26.8 & 22.5 & 21.4 & 38.8 \\
\hline 22 & Bheduasol & 134.2 & 378.2 & 29.1 & 470.5 & 79.7 & 1507 & 8.1 & 81.5 & 68.5 & 76.2 & 66 & 144 \\
\hline Mean & & 193.8 & 342.6 & 140.4 & 213.0 & 40.0 & 455.8 & 17.4 & 155.9 & 34.5 & 31.5 & 39.2 & 44.8 \\
\hline Maximum & & 310.7 & 549.7 & 479.9 & 470.5 & 142 & 1507 & 60.9 & 620.6 & 96.8 & 76.2 & 94 & 144 \\
\hline Minimum & & 85.4 & 244.5 & 14.2 & 25.2 & 9.9 & 70.2 & 2.2 & 27.2 & 12.9 & 12.9 & 7.1 & 8.5 \\
\hline Loc no. & Locatio & name & & $\begin{array}{l}\mathrm{Ca}^{2+} \\
(\mathrm{mg} / \mathrm{l})\end{array}$ & & & $\begin{array}{l}\mathrm{K}^{+} \\
(\mathrm{mg} \\
\end{array}$ & & & & $\begin{array}{l}\mathrm{Fe}^{2+} \\
(\mathrm{mg} /\end{array}$ & & \\
\hline & & & & PrM & & & PrN & & PoM & & PrM & & PoM \\
\hline 1 & Hatgran & & & 104.1 & & & 5.3 & & 25.3 & & 45.2 & & 0.8 \\
\hline 2 & Salukda & & & 36.4 & & & 1.5 & & 25 & & 1.9 & & 0.8 \\
\hline 3 & Kajalku & & & 111.6 & & & 3.1 & & 26.1 & & 0.4 & & 0.8 \\
\hline 4 & Belut & & & 84.3 & & & 2.1 & & 17.6 & & 0.4 & & 0.9 \\
\hline 5 & Gottary & & & 119.2 & & & 1.8 & & 14.2 & & 1.7 & & 0.9 \\
\hline 6 & Gopaldi & & & 98.4 & & & 3.6 & & 9.2 & & 7.4 & & 0.7 \\
\hline 7 & Phulkus & & & 33.6 & & & 1.9 & & 8.3 & & 1.5 & & 0.7 \\
\hline 8 & Bhutam & & & 57.6 & & & 1.3 & & 5.4 & & 1.3 & & 0.8 \\
\hline 9 & Kadam & & & 46.2 & & & 3.2 & & 9.7 & & 0.2 & & 2.9 \\
\hline 10 & Chaitan & & & 32.4 & & & 1.3 & & 9.9 & & 11.8 & & 0.8 \\
\hline 11 & Baga & & & 48.7 & & & 0.9 & & 7.8 & & 5.5 & & 0.6 \\
\hline 12 & Chakalt & & & 127.2 & & & 2.2 & & 7.1 & & 3.2 & & 0.8 \\
\hline 13 & Jirra & & & 197.2 & & & 5.8 & & 9.2 & & 0.9 & & 0.8 \\
\hline 14 & Bagdihe & & & 32.5 & & & 1.7 & & 11.2 & & 3.2 & & 0.9 \\
\hline 15 & Indpur & & & 60.5 & & & 1.9 & & 10.6 & & 2.5 & & 1.2 \\
\hline 16 & Bhatra & & & 43.2 & & & 3.9 & & 12.8 & & 2.1 & & 0.8 \\
\hline 17 & Rautara & & & 85.6 & & & 2.7 & & 15.4 & & 0.6 & & 0.7 \\
\hline 18 & Araldih & & & 44.8 & & & 5.0 & & 17.3 & & 17.1 & & 0.7 \\
\hline 19 & Kuchaip & & & 44.3 & & & 0.9 & & 20.5 & & 0.8 & & 0.6 \\
\hline
\end{tabular}


Table 3 (continued)

\begin{tabular}{|c|c|c|c|c|c|c|c|}
\hline \multirow[t]{2}{*}{ Loc no. } & \multirow[t]{2}{*}{ Location name } & \multicolumn{2}{|l|}{$\begin{array}{l}\mathrm{Ca}^{2+} \\
(\mathrm{mg} / \mathrm{l})\end{array}$} & \multicolumn{2}{|c|}{$\begin{array}{l}\mathrm{K}^{+} \\
(\mathrm{mg} / \mathrm{l})\end{array}$} & \multicolumn{2}{|c|}{$\begin{array}{l}\mathrm{Fe}^{2+} \\
(\mathrm{mg} / \mathrm{l})\end{array}$} \\
\hline & & PrM & PoM & PrM & PoM & PrM & PoM \\
\hline 20 & Gobindapur & 31.9 & 84.3 & 1.7 & 5.1 & 2.5 & 1.5 \\
\hline 21 & Botkula & 52.4 & 155.5 & 2.4 & 5.4 & 0.8 & 1.5 \\
\hline 22 & Bheduasol & 179.8 & 403.2 & 4.2 & 11 & 1.3 & 0.4 \\
\hline Mean & & 76.0 & 138.1 & 2.7 & 12.9 & 5.1 & 0.9 \\
\hline Maximum & & 197.2 & 403.2 & 5.8 & 26.1 & 45.2 & 2.9 \\
\hline Minimum & & 31.9 & 29.3 & 0.9 & 5.1 & 0.2 & 0.4 \\
\hline
\end{tabular}

Table 4 Ranges of physicochemical parameters of groundwater and comparative status

\begin{tabular}{|c|c|c|c|c|c|c|c|c|c|}
\hline \multirow[t]{3}{*}{ Sl. No. } & \multirow{3}{*}{$\begin{array}{l}\text { Measured } \\
\text { Parameter }\end{array}$} & \multicolumn{2}{|l|}{$\operatorname{PrM}$} & \multicolumn{2}{|l|}{ PoM } & \multirow{3}{*}{$\begin{array}{l}\text { Acceptable } \\
\text { limit }\end{array}$} & \multicolumn{3}{|l|}{ BIS (IS 10500:2012) } \\
\hline & & \multirow[t]{2}{*}{$\begin{array}{l}\text { Measured } \\
\text { Ranges }\end{array}$} & \multirow[t]{2}{*}{ Mean } & \multirow[t]{2}{*}{$\begin{array}{l}\text { Measured } \\
\text { Ranges }\end{array}$} & \multirow[t]{2}{*}{ Mean } & & \multirow[t]{2}{*}{$\begin{array}{l}\text { Permissible limit in the } \\
\text { absence of alternate source }\end{array}$} & \multicolumn{2}{|c|}{$\begin{array}{l}\text { No. of sam- } \\
\text { ples above } \\
\text { acceptable } \\
\text { limit }\end{array}$} \\
\hline & & & & & & & & PrM & PoM \\
\hline 1 & $\mathrm{pH}$ & $\begin{array}{l}5.8 \\
7.0\end{array}$ & 6.6 & $\begin{array}{l}6.3 \\
7.0\end{array}$ & 6.7 & $\begin{array}{l}6.5 \\
8.5\end{array}$ & $\begin{array}{l}\text { No } \\
\text { relaxation }\end{array}$ & 12 & 16 \\
\hline 2 & $\begin{array}{l}\mathrm{EC} \\
(\mu \mathrm{S} / \mathrm{cm})\end{array}$ & $\begin{array}{l}271 \\
3921\end{array}$ & 945.6 & $\begin{array}{l}57 \\
3684\end{array}$ & 1187.5 & - & - & - & - \\
\hline 3 & $\begin{array}{l}\text { TDS } \\
(\mathrm{ppm})\end{array}$ & $\begin{array}{l}136 \\
1843\end{array}$ & 469 & $\begin{array}{l}165 \\
1849\end{array}$ & 632.3 & 500 & 2000 & 7 & 11 \\
\hline 4 & $\begin{array}{l}\mathrm{HCO}_{3}^{-}- \\
(\mathrm{mg} / \mathrm{l})^{-}\end{array}$ & $\begin{array}{l}85.4 \\
310.7\end{array}$ & 193.8 & $\begin{array}{l}244.5 \\
549.7\end{array}$ & 342.6 & 200 & 600 & 11 & 22 \\
\hline 5 & $\begin{array}{l}\mathrm{SO}_{4}^{2-} \\
(\mathrm{mg} / \mathrm{l})\end{array}$ & $\begin{array}{l}9.9 \\
142\end{array}$ & 40 & $\begin{array}{l}70.2 \\
1507\end{array}$ & 455.8 & 200 & 400 & 0 & 17 \\
\hline 6 & $\begin{array}{l}\mathrm{Cl}^{-} \\
(\mathrm{mg} / \mathrm{l})\end{array}$ & $\begin{array}{l}14.2 \\
479.9\end{array}$ & 140.4 & $\begin{array}{l}25.2 \\
470.5\end{array}$ & 213 & 250 & 1000 & 4 & 8 \\
\hline 7 & $\begin{array}{l}\mathrm{NO}_{3}^{-} \\
(\mathrm{mg} / \mathrm{l})\end{array}$ & $\begin{array}{l}2.2 \\
60.9\end{array}$ & 17.4 & $\begin{array}{l}27.2 \\
620.6\end{array}$ & 155.9 & 45 & $\begin{array}{l}\text { No } \\
\text { relaxation }\end{array}$ & 2 & 18 \\
\hline 8 & $\begin{array}{l}\mathrm{Fe}^{2+} \\
(\mathrm{mg} / \mathrm{l})\end{array}$ & $\begin{array}{l}0.2 \\
45.2\end{array}$ & 5.1 & $\begin{array}{l}0.4 \\
2.9\end{array}$ & 0.9 & 0.3 & $\begin{array}{l}\text { No } \\
\text { relaxation }\end{array}$ & 21 & 22 \\
\hline 9 & $\begin{array}{l}\mathrm{Ca}^{2+} \\
(\mathrm{mg} / \mathrm{l})\end{array}$ & $\begin{array}{l}31.9 \\
197.2\end{array}$ & 76.0 & $\begin{array}{l}29.45 \\
403.2\end{array}$ & 138.1 & 75 & 200 & 9 & 17 \\
\hline 10 & $\begin{array}{l}\mathrm{Mg}^{2+} \\
(\mathrm{mg} / \mathrm{l})\end{array}$ & $\begin{array}{l}7.1 \\
94.0\end{array}$ & 39.2 & $\begin{array}{l}8.5 \\
144.0\end{array}$ & 44.8 & 30 & 100 & 15 & 15 \\
\hline 11 & $\begin{array}{l}\mathrm{Na}^{+} \\
(\mathrm{mg} / \mathrm{l})\end{array}$ & $\begin{array}{l}12.9 \\
96.8\end{array}$ & 34.5 & $\begin{array}{l}12.9 \\
76.2\end{array}$ & 31.5 & - & - & - & - \\
\hline 12 & $\begin{array}{l}\mathrm{K}^{+} \\
(\mathrm{mg} / \mathrm{l})\end{array}$ & $\begin{array}{l}0.9 \\
5.8\end{array}$ & 2.7 & $\begin{array}{l}5.1 \\
26.1\end{array}$ & 12.9 & - & - & - & - \\
\hline 13 & $\mathrm{TH}$ & $\begin{array}{l}109 \\
720\end{array}$ & 339.6 & $\begin{array}{l}70 \\
1596\end{array}$ & 491 & 100 & 500 & 22 & 21 \\
\hline
\end{tabular}

and PoM. Table 5 represents the ranges of estimated values of these parameters and seasonal variations for all the studied locations. These were estimated to acquire a better understanding of irrigational water quality for the entire block. Inundated nature of surface drainage network, thin residual lateritic soil cover and absence of shallow aquifer with primary porosity make the irrigation practices of the block more dependent on its groundwater, especially during PrM season. Excessive withdrawal of groundwater and the use of fertilizers for irrigation, at the eastern side of the block, are mostly responsible for gradual degradation of the water quality. Rapid and severe declination of availability of groundwater in many locations (L1; L2; L9; L11; L13 and L19) seemed to be crucial during PrM. Table 6 reveals 
(a) Pre-monsoon

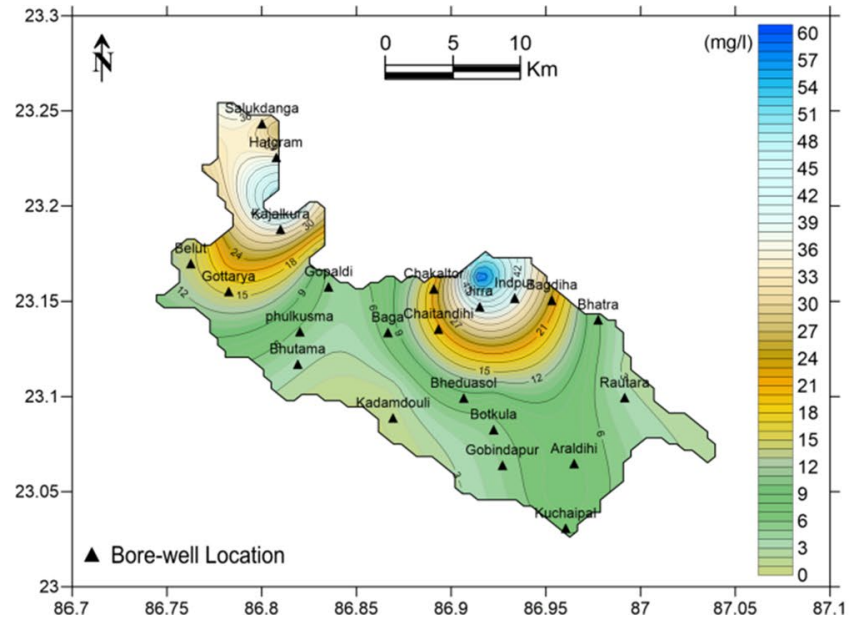

Fig. 7 Spatial variation of $\mathrm{NO}_{3}{ }^{2-}$ a PrM; b PoM

(a) Pre-monsoon

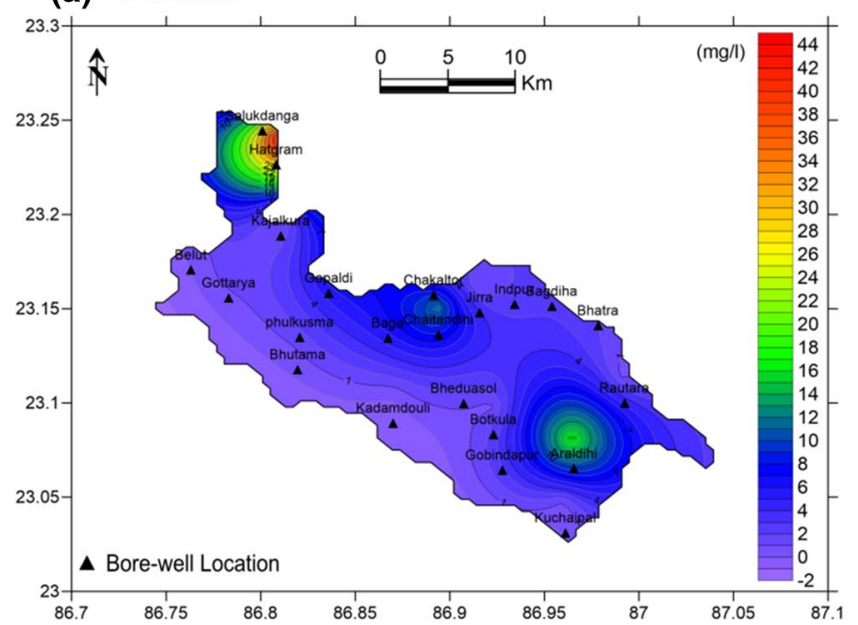

Fig. 8 Spatial distribution of $\mathrm{Fe}^{2+} ; \mathbf{a}$ PrM; b PoM

the classification of groundwater samples according to the standards specified for water quality parameters by WHO (2017). It may be noted from Table 6, parameters like TH, EC, TDS, RSC and MAR in some locations of the blocks are in vulnerable limits, majorly during PoM period.

\section{Sodium adsorption ratio (SAR)}

Figure $9 \mathrm{a}, \mathrm{b}$ represents the plots of SAR value in US salinity diagram for the classification of irrigation waters (Richards 1954) for both PrM and PoM period. The maximum SAR value in PrM season was observed at Indpur (18.6) and Salukdanga (0.8) during PoM. Increase in SAR value was observed during PrM than PoM and is constricted at the Eastern region of the block. Ground water (b) Post-monsoon

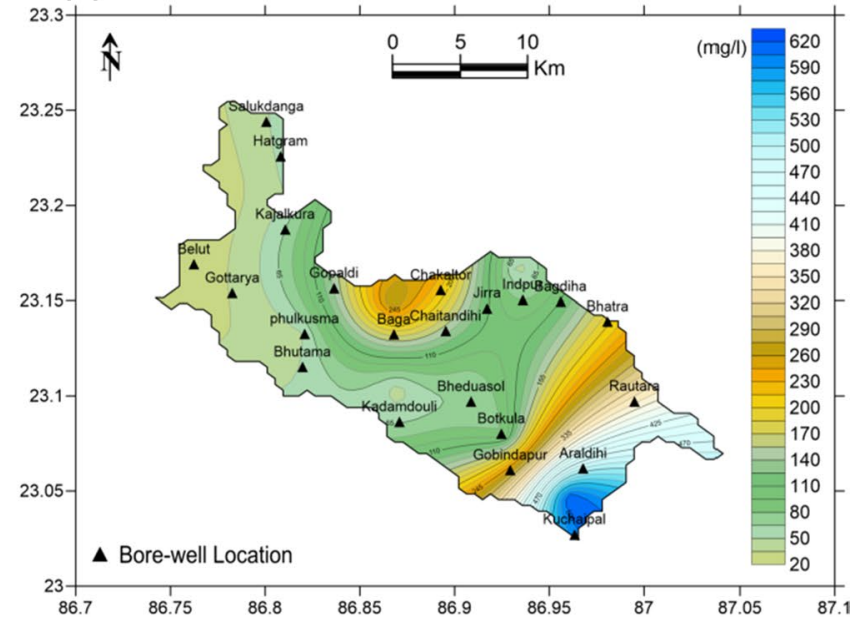

(b) Post-monsoon

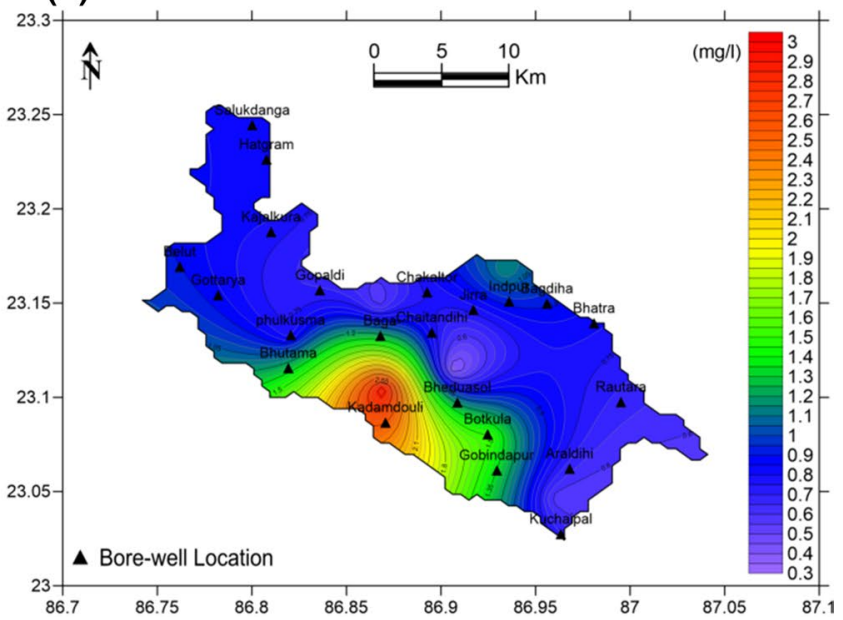

level head plot (Fig. 4a, b) reveals that this area is one of the most prominent recharge zones during pre-monsoon time. According to the standard specified for water quality indices the SAR value $<20$ is considered to be excellent for irrigation (Richards 1954). In the present study, the average SAR value during PrM is 9.93 and during PoM is 0.46 , that reveals the water of the Block is well suitable for irrigation. Plots on US Salinity Diagram (Richards 1954), based on the SAR values, both for the PrM and PoM, respectively, reveal that overall water of the block fall in low sodium hazard zones and constricted at the basal-most portion of C1-S1, C2-S1, C3-S1 classes, both during PoM and PrM. Therefore, the water of the block is moderately suitable for irrigation. 
Table 5 Values of estimated water quality parameters/indices for pre-monsoon and post-monsoon seasons

\begin{tabular}{|c|c|c|c|c|c|c|c|c|c|c|c|c|c|c|c|}
\hline \multirow[t]{2}{*}{ Loc no. } & \multirow[t]{2}{*}{ Location } & \multicolumn{2}{|l|}{ SSP } & \multicolumn{2}{|l|}{ SAR } & \multicolumn{2}{|l|}{ MAR } & \multicolumn{2}{|l|}{ RSC } & \multicolumn{2}{|l|}{$\mathrm{KR}$} & \multicolumn{2}{|l|}{ PI } & \multicolumn{2}{|l|}{ TC } \\
\hline & & PrM & PoM & PrM & PoM & PrM & PoM & PrM & PoM & PrM & PoM & PrM & PoM & rM & PoM \\
\hline 1 & Hatg & 32.80 & 43.41 & 1.41 & 0.77 & 41.61 & 30.33 & 4.97 & 3 & 17 & 0.50 & 22 & 2 & 7.05 & 9.16 \\
\hline L2 & Salukdanga & 31.93 & 44.10 & 1.23 & 0.78 & 74.02 & 36.69 & -1 & 3 & 6 & 1 & 66 & 03 & 33 & 9.26 \\
\hline L3 & Kaja & 16.01 & 42.65 & 0.52 & 0.76 & 32.55 & 31.45 & - & 2. & & & 7 & & & 9.00 \\
\hline L4 & Belut & 14.97 & 23.08 & 0.48 & 0.48 & 43.61 & 52.44 & -3.71 & -0 & & 0 & & & 51 & 0.73 \\
\hline L5 & Got & 9. & 18. & 0.36 & 0.42 & 80 & 49 & -1 & & U & 0 & & 42.33 & 73 & 2.08 \\
\hline 6 & Gop & 13.15 & 14.9 & 0.37 & 0.41 & 31.94 & 30.63 & -4 & - & 4 & 0 & 17 & 3 & 02 & 3.81 \\
\hline 7 & Phull & 19.93 & 19.06 & 0.62 & 0.50 & 74.07 & 37.11 & -4.08 & -2 & 0.24 & 0.20 & 38.71 & 43 & 10.44 & 11.55 \\
\hline L8 & lut: & 13.63 & 8.92 & 0.29 & 0.31 & 23.22 & 50.84 & -1 & - & 5 & 0.09 & 84 & 24 & & $8.9^{\prime}$ \\
\hline L9 & $\mathrm{K}$ & 1 & 10. & 0.27 & 0.22 & 52.19 & 31.24 & & 0.45 & 0.12 & 0.09 & 37 & 4 & 9 & 13.70 \\
\hline L10 & Chai & 19.97 & 10.13 & 0.36 & 0.48 & 32.19 & 36.74 & - & 1 & 0.24 & 0.10 & 51 & 20.0 & 5.08 & 30.52 \\
\hline 11 & $\mathrm{Ba}$ & 1 & 10. & 0 & 0. & 69 & 21 & & & & & & & & 8.1 \\
\hline L12 & Cha & 3 & 13. & 0 & 0.48 & 3 & 32.77 & - & - & 7 & & 38 & & & 3.6 \\
\hline L13 & $\mathrm{J}$ & & 1 & & & 3 & 5 & - & & & & & & & 22.2 \\
\hline L14 & $\mathrm{Ba}$ & 2 & 14 & 0 & 0 & 2 & 39.20 & -0 & - & & 0. & 10 & & & 19.7 \\
\hline L15 & Indpur & 24.40 & 18.59 & 0.77 & 0.45 & 50.02 & 45.68 & -3.65 & -0 & 0.32 & 0.19 & 43.42 & 45 & 10.35 & 16.2 \\
\hline L16 & Bhatra & 24.49 & 13.67 & 0.80 & 0.36 & 67.84 & 34.08 & -2.45 & -5 & 0.31 & 0.13 & 47.10 & 30 & 13.06 & 19.47 \\
\hline L17 & Rautara & 10.37 & 11.55 & 0.30 & 0.28 & 45.15 & 26.33 & -3.87 & -7.50 & 0.11 & 0.10 & 32.62 & 25.48 & 12.57 & 19.69 \\
\hline L18 & Araldihi & 21.62 & 9.84 & 0.47 & 0.24 & 40.41 & 20.09 & -0.81 & -8.63 & 0.24 & 0.08 & 56.26 & 22.17 & 7.62 & 19.32 \\
\hline L19 & Kuchaipal & 20.22 & 8.95 & 0.48 & 0.35 & 42.09 & 15.41 & -1.50 & 34.47 & 0.25 & 0.06 & 51.79 & 51.03 & 7.03 & 64.57 \\
\hline L20 & Gobindapur & 19.98 & 12.82 & 0.61 & 0.30 & 74.74 & 42.00 & -4.12 & -3.06 & 0.24 & 0.13 & 38.42 & 36.40 & 10.05 & 12.40 \\
\hline $\mathrm{L} 21$ & Botkula & 21.76 & 9.20 & 0.56 & 0.58 & 40.48 & 29.36 & -0.63 & -6.75 & 0.26 & 0.09 & 55.80 & 25.38 & 9.34 & 16.27 \\
\hline L22 & Bheduasol & 17.55 & 10.11 & 0.78 & 0.53 & 37.97 & 37.23 & -12.29 & -25.92 & 0.21 & 0.10 & 25.54 & 16.37 & 19.67 & 41.6 \\
\hline Mean & & 18.70 & 17.41 & 0.57 & 0.46 & 45.99 & 35.75 & -3.89 & -3.02 & 0.23 & 0.18 & 42.85 & 42.38 & 11.74 & 19.6 \\
\hline Maxin & & 32.80 & 44.10 & 1.41 & 0.78 & 74.74 & 55.51 & -0.06 & 34.47 & 0.47 & 0.51 & 75.40 & 102.03 & 19.67 & 64.5 \\
\hline Minimum & & 9.07 & 8.92 & 0.27 & 0.22 & 23.22 & 15.41 & -12.29 & -25.92 & 0.09 & 0.06 & 21.35 & 16.37 & 5.08 & 9.00 \\
\hline
\end{tabular}

\section{Soluble sodium percentage (SSP) and permeability index (PI)}

The absorption of sodium by clay particles is facilitated due to the release of calcium and magnesium ions resulting in internal drainage patterns in the soil, causing high sodium ion concentration in soil (Todd 1980). The SSP values range from $3.62-26.91 \mathrm{meq} / \mathrm{l}$ in pre-monsoon season to $6.45-22.37 \mathrm{meq} / \mathrm{l}$ during post-monsoon. Figure 10a, b represents the 'Wilcox Diagram' as represented by the plots of SSP versus the respective EC values (Wilcox 1955). It is evident from the plots that majority of the studied water samples are grouped in "Very Good to Good" category, for both during PoM and PrM. During PrM water of L22 falls in unsuitable category, whereas L10; L11; L12 and L13 grouped in doubtful to unsuitable classes during PoM. 'Permeability Index' (PI) of the studied water samples of the block (after Doneen 1964) are represented by Fig. $11 \mathrm{a}, \mathrm{b}$, and the water quality data are constricted mostly of Class I and Class II during PrM. The water of a few locations of extreme $\mathrm{W}$ and NW side (L1; L2; L3) grouped in class III during PoM waters, which are categorized as good for irrigation.

\section{Residual sodium carbonate (RSC)}

Residual sodium carbonate values should be preferably less than 1.25 to be rendered suitable for irrigation. The present study shows that RSC values range between - 12.29 at Bheduasol (L22) - 0.06 at Bagdiha (L14) in PRM and - 25.92 at Bheduasol (L22) - 3.42 at Salukdanga (L2) during POM and almost $100 \%$ of the water samples have RSC $<1.25$ during PRM but during POM, except L1. L2 and L3 all water samples in this area fall in the safe category (Table 6).

\section{Magnesium adsorption ratio (MAR)}

MAR categorizes water into two broad classes-water having MAR $<50$ is considered suitable for irrigation whereas water with MAR $>50$ is considered unsuitable, based on which it can be concluded that the water samples 
Table 6 Classification of groundwater samples according to the standards of WHO (2017)

\begin{tabular}{|c|c|c|c|c|c|c|}
\hline \multirow[t]{2}{*}{ Parameters } & \multirow[t]{2}{*}{ Range } & \multirow[t]{2}{*}{ Class } & \multicolumn{2}{|c|}{$\begin{array}{l}\text { Number of the } \\
\text { samples }\end{array}$} & \multicolumn{2}{|c|}{$\begin{array}{l}\text { Percentage of } \\
\text { the samples }(\%)\end{array}$} \\
\hline & & & Pre & Post & Pre & Post \\
\hline \multirow{5}{*}{$\begin{array}{l}\mathrm{EC} \\
(\mu \mathrm{S} / \mathrm{cm})\end{array}$} & $<250$ & Excellent & 0 & 1 & 0 & 5 \\
\hline & $250-750$ & Good & 11 & 7 & 50 & 32 \\
\hline & $750-2000$ & Permissible & 10 & 11 & 45 & 50 \\
\hline & $2000-3000$ & Doubtful & 0 & 2 & 0 & 9 \\
\hline & $>3000$ & Unsuitable & 1 & 1 & 5 & 5 \\
\hline \multirow{4}{*}{$\begin{array}{l}\text { TDS } \\
(\mathrm{ppm})\end{array}$} & $<1000$ & Fresh & 21 & 19 & 95 & 86 \\
\hline & $1000-10,000$ & Brackish & 1 & 3 & 5 & 14 \\
\hline & $10,000-100,000$ & Saline & 0 & 0 & 0 & 0 \\
\hline & $>100,000$ & Brine & 0 & 0 & 0 & 0 \\
\hline \multirow[t]{4}{*}{$\mathrm{TH}$} & $<75$ & Soft & 0 & 1 & 0 & 5 \\
\hline & $75-150$ & Moderately Hard & 3 & 2 & 14 & 9 \\
\hline & $150-300$ & Hard & 8 & 1 & 36 & 5 \\
\hline & $>300$ & Very Hard & 11 & 18 & 50 & 82 \\
\hline \multirow[t]{5}{*}{ SSP } & $<20$ & Excellent & 14 & 18 & 64 & 82 \\
\hline & $20-40$ & Good & 8 & 1 & 36 & 5 \\
\hline & $40-60$ & Permissible & 0 & 3 & 0 & 14 \\
\hline & $60-80$ & Doubtful & 0 & 0 & 0 & 0 \\
\hline & $>80$ & Unsuitable & 0 & 0 & 0 & 0 \\
\hline \multirow[t]{3}{*}{ RSC } & $<1.25$ & Low & 22 & 18 & 100 & 82 \\
\hline & $1.25-2.50$ & Medium & 0 & 0 & 0 & 0 \\
\hline & $>2.50$ & High & 0 & 4 & 0 & 18 \\
\hline \multirow[t]{4}{*}{ SAR } & $0-10$ & Excellent & 16 & 22 & 73 & 100 \\
\hline & $10-18$ & Good & 5 & 0 & 23 & 0 \\
\hline & $18-26$ & Permissible & 1 & 0 & 5 & 0 \\
\hline & $>26$ & Doubtful & 0 & 0 & 0 & 0 \\
\hline \multirow[t]{2}{*}{ MAR } & $<50$ & Suitable & 14 & 19 & 64 & 86 \\
\hline & $>50$ & Unsuitable & 8 & 3 & 36 & 14 \\
\hline \multirow[t]{2}{*}{ KR } & $<1$ & Suitable & 22 & 22 & 100 & 100 \\
\hline & $>1$ & Unsuitable & 0 & 0 & 0 & 0 \\
\hline
\end{tabular}

in the Indpur block are suitable for irrigation in pre-monsoon except L2, L5, L7, L9, L11, L16 and L20. Moreover, during POM, except L4 and L13 the MAR values are under the permissible limit, which is considered safe and suitable for irrigation.

\section{Kelly's ratio (KR)}

Waters with a KI value $<1$ are considered suitable for irrigation, while those with greater ratios are rendered unsuitable. During PRM, KR values vary between 0.09 and 0.47 and during POM the values vary between 0.06 and 0.51 . According to Kelly's ratio, water analysed is suitable for irrigation during both periods.

\section{Hydro-geochemical facies}

The Piper Trilinear diagram is represented by plotting the major cations and anions to determine the geochemical evolution of groundwater. This diagram is a graphical representation of the chemistry of water samples and its drinking suitability. The cations and anions are presented by distinct ternary plots. The acmes of the cation plot are calcium, magnesium and sodium plus potassium cations. The acmes of the anion plot are sulfate, chloride and carbonate plus hydrogen carbonate anions. The two triangle plots are then calculated onto a diamond. The diamond is a matrix transformation of a graph of the anions (sulfate + chloride/total anions) and cations (sodium + potassium/total cations). Piper diagram can foretell the water type in three ways-fresh type, sulfate 
(a) Pre-monsoon

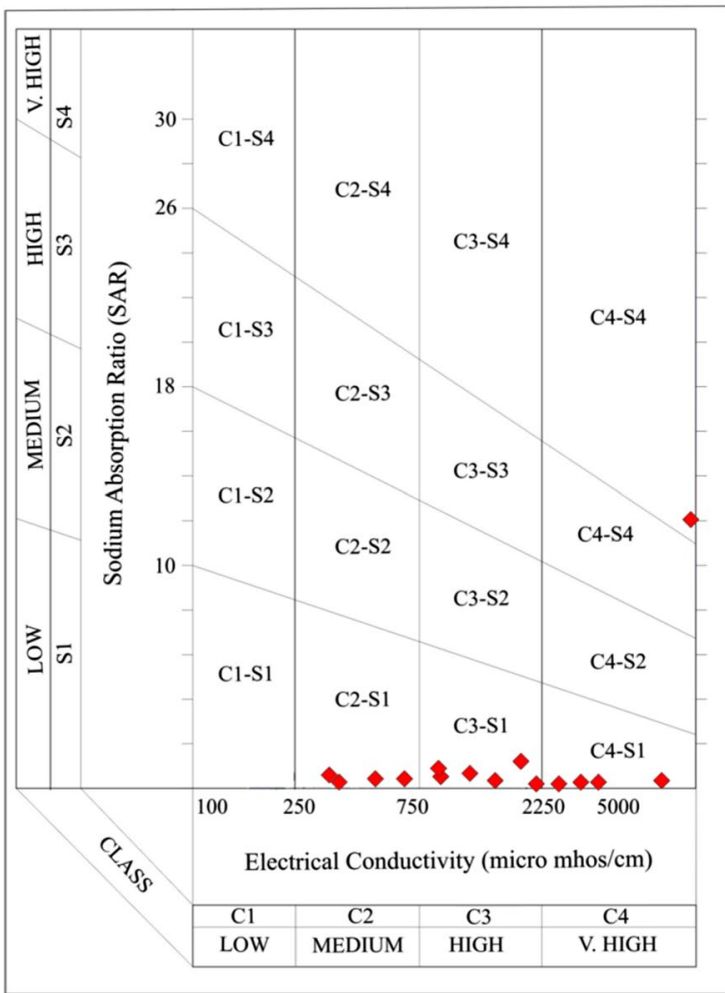

(b) Post-monsoon

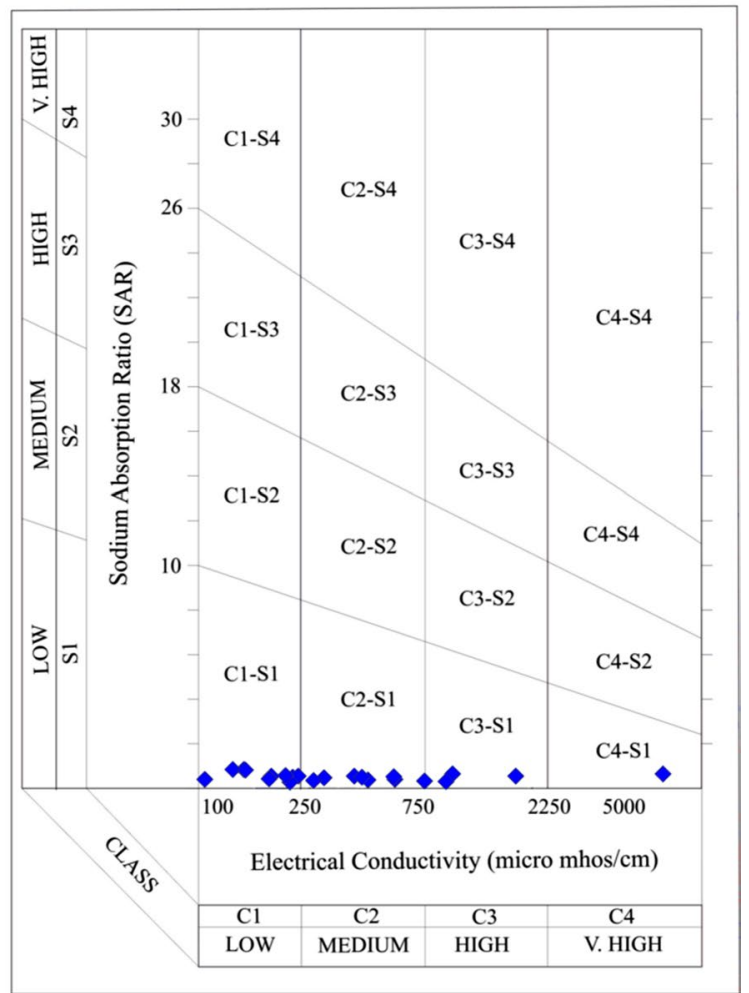

Fig. 9 US salinity diagram; a PrM; b PoM (after Richards 1954)

(a) Pre-monsoon

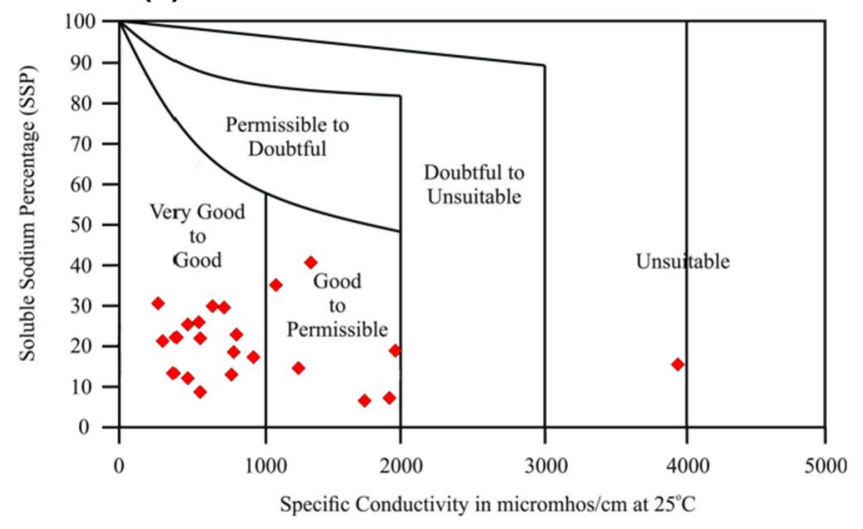

Fig. 10 Wilcox diagram a PrM; b PoM

type and saline type. This diagram divulges similarities and differences among water samples because those with similar qualities will tend to project together as groups (Todd 1980).

Piper trilinear diagram (Piper 1944) is useful to bring out chemical relationships among water in more definite terms (Apambire et al. 1997). Major ions are plotted as cation and anion in percentages of mili-equivalents in two base triangles. Figure $12 \mathrm{a}, \mathrm{b}$ shows the (b) Post-monsoon

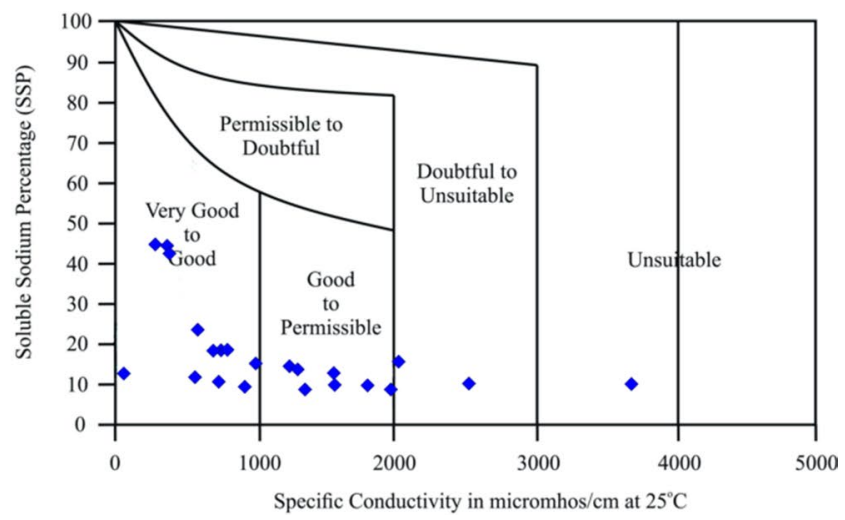

Piper diagram of the water during PrM and PoM seasons, respectively. It indicates that during $\operatorname{PrM}, 60 \%$ of the samples falls in Calcium-Magnesium-Bicarbonate facies whereas $40 \%$ of the samples falls within Calcium-Magnesium-Sulphate-Chloride facies (Fig. 12a). The overall geochemical facies change in PoM, where nearly $68 \%$ of the samples belong to Calcium-Magnesium-Sulphate-Chloride facies (i.e. in sulphate region), 
(a) Pre-monsoon

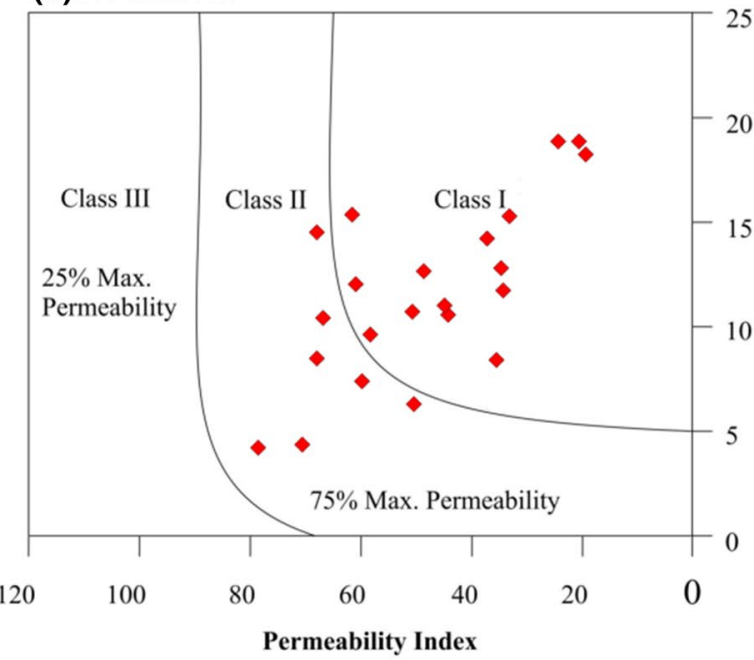

Fig. 11 Doneen's chart for P.I. values; a PrM; b PoM (b) Post-monsoon

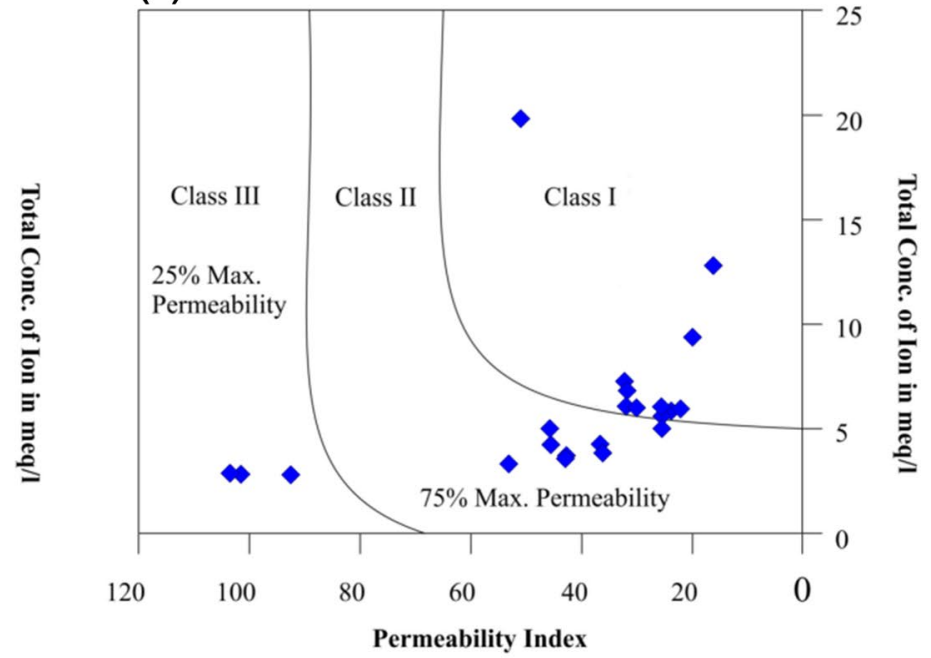

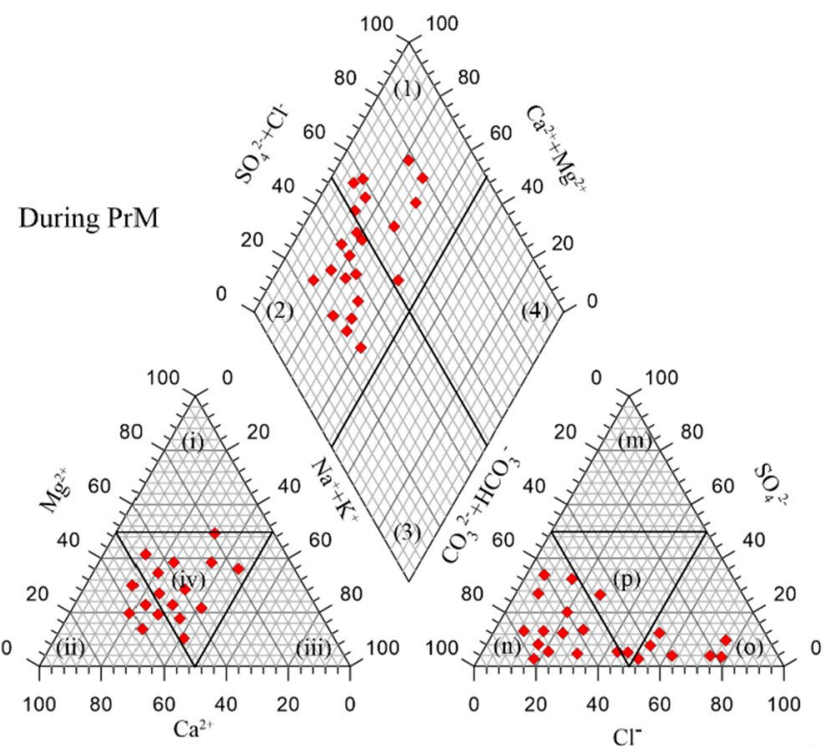

(a) Piper diagram for PrM

Trilinear diagram illustrating cation concentration
Trilinear diagram illustrating anion concentration

\section{$\% \mathrm{meq} /$}

Trilinear diagram illustrating

(b) Piper diagram for PoM

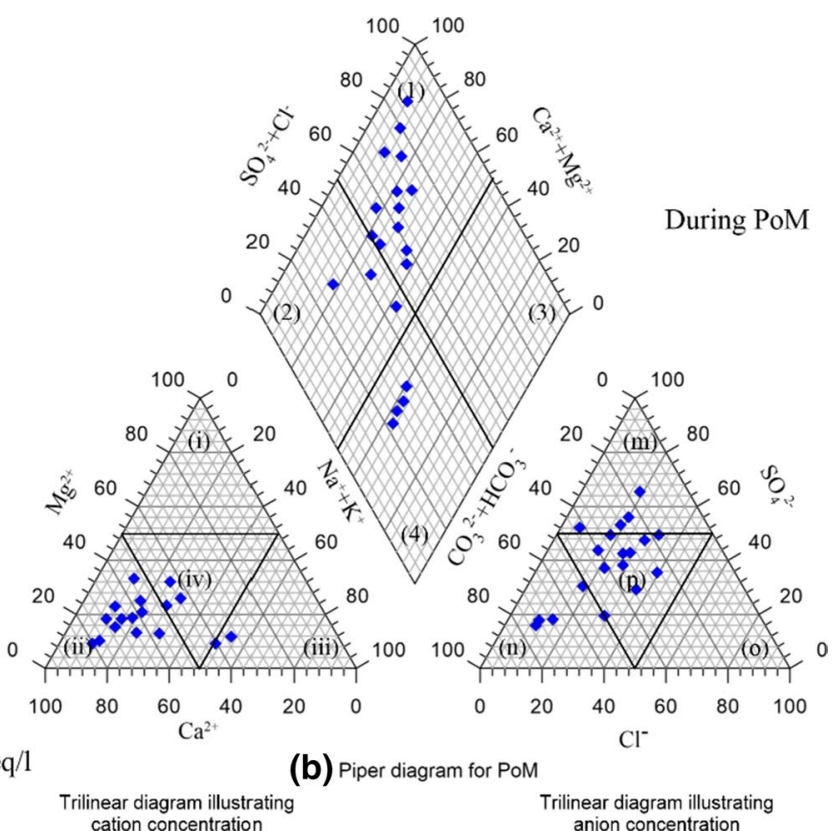

sium; (ii) Calcium; (iii) Sodium Potassium; (iv) Mixed Zone; (m) Sulfate; (n) Bicarbonate; (o) Chloride; (p) Mixed Zone

Fip. 12 Piper trilinear diagram; a PrM; b PoM. Here (1) Calciun Magnesium Sulfate Chloride; (2) Calcium Magnesium Bicarbonate; (3) Sodium Bicarbonate; (4) Sodium Chloride Sulfate; (i) Magne-

$14 \%$ fall in Calcium-Magnesium-Bicarbonate and 18\% Sodium-Chloride-Sulphate facies, respectively (i.e. in fresh and alkali rich category). During PrM, the dominant cations were $\mathrm{Ca}^{2+}>\mathrm{Na}^{+}+\mathrm{K}^{+}>\mathrm{Mg}^{2+}$ (Left triangle), and the dominant anions were $\mathrm{HCO}_{3}{ }^{-}+\mathrm{CO}_{3}{ }^{2-}>\mathrm{Cl}^{-}>\mathrm{SO}^{2-}$ (Right triangle) and during PoM, the dominant cations were $\mathrm{Ca}^{2+}>\mathrm{Na}^{+}+\mathrm{K}^{+}>\mathrm{Mg}^{2+}$ (Left triangle) similar to Prm, however, the dominant anions were $\mathrm{SO}_{4}{ }^{2-}>\mathrm{HCO}_{3}{ }^{-}+\mathrm{CO}_{3}{ }^{2-}>\mathrm{Cl}^{-}$(Right triangle). Most of the locations of the studied block such as Chakaltor (L12), Jirra (L13), Bheduasol (L22), exaggerated use of sulphate fertilizers like, ammonium sulphate, calcium sulphate for cultivation to extract maximum yield of crops from comparatively lesser fertile residual metasediment soil cover, expected to be the prime reason for such change in hydro-geochemical facies during PoM. Thus, it indicates that as whole water is fresh in nature during PrM whereas comparatively sulphate rich in PoM. 


\section{Total hardness}

Based on the TH values, water is grouped in four major classes and are represented in Table 6 (after Sawyer and McCarty 1967). Obtained values of TH for both PrM and PoM (Table 2) revealed that the limiting values range between $107 \mathrm{mg} / \mathrm{l}$ at Bagdiha (L22) and $720 \mathrm{mg} / \mathrm{l}$ at Bheduasol (L22) with an average of $339.6 \mathrm{mg} / \mathrm{l}$ in PrM. During PoM, it ranges between 70 at Salukdanga (L2) and $1596 \mathrm{mg} / \mathrm{l}$ at Bheduasol (L22), with an average of $491 \mathrm{mg} / \mathrm{l}$. It is pertinent from both the sampling seasons that most of the water samples were found to be hard to very hard in type. According to (BIS 2012-IS10500:2012), the permissible range of total alkalinity (TA) in groundwater is $200-600 \mathrm{mg} / \mathrm{l}$. The total alkalinity values for all the examined water samples during both sessions fall within the recommended values (Table 2).

\section{Water quality index}

Water quality index (WQI) is one of the most effective measures to estimate the quality of water in concern to public health and served as an important tool for the concerned citizens and policy makers (Ramakrishnalah et al. 2009; Alobaidy et al. 2010; Lumb et al. 2011). The Water Quality Index (WQI) is a method generally used as a part of surveying the general water quality using a group of affecting parameters which synchronizes substantial amounts of information to a single number, usually dimensionless, in a simple reproducible manner (Abbasi and Abbasi 2012).

According to Ramakrishnalah et al. (2009), three prime steps need to be followed for determining WQI. The first step consists of assigning a weight $\left(W_{i}\right)$ to each of the 13 parameters, according to its relative importance in the quality of water for drinking purposes.

In the second step, the relative weight is measured from the following equations:

$W_{i}=\frac{w_{i}}{\sum_{i=1}^{n} w_{i}}$

where $W_{i}$ is the relative weight, $w_{i}$ is the weight of each of the parameter and $n$ is the number of parameters.

Finally, in the third step, a quality rating scale $\left(q_{i}\right)$ is assigned for each parameter by dividing its concentration in each water sample by its respective standard according to the guidelines laid down by BIS (IS10500:2012) and the result is multiplied by 100 :

$q_{i}=\left(\frac{C_{i}}{S_{i}}\right) * 100$
Table 7 Relative weight of chemical parameters for WQI index

\begin{tabular}{|c|c|c|c|c|}
\hline \multirow[t]{2}{*}{ Parameters } & \multirow[t]{2}{*}{ BIS (IS 10500:2012) } & \multirow[t]{2}{*}{ Weight $\left(\mathrm{w}_{i}\right)$} & \multicolumn{2}{|c|}{$\begin{array}{l}\text { Relative } \\
\text { weight }\left(W_{i}\right)\end{array}$} \\
\hline & & & PrM & PoM \\
\hline $\mathrm{pH}$ & $6.5-8.5$ & 10 & 0.182 & 0.138 \\
\hline $\begin{array}{l}\text { EC } \\
(\mu \mathrm{S} / \mathrm{cm})\end{array}$ & - & 4 & 0.073 & 0.074 \\
\hline $\begin{array}{l}\text { TDS } \\
(\mathrm{ppm})\end{array}$ & $300-600$ & 4 & 0.073 & 0.041 \\
\hline $\begin{array}{l}\mathrm{Ca}^{2+} \\
(\mathrm{mg} / \mathrm{l})\end{array}$ & $75-200$ & 5 & 0.091 & 0.129 \\
\hline $\begin{array}{l}\mathrm{Mg}^{2+} \\
(\mathrm{mg} / \mathrm{l})\end{array}$ & $30-100$ & 9 & 0.164 & 0.111 \\
\hline $\begin{array}{l}\mathrm{Cl}^{-} \\
(\mathrm{mg} / \mathrm{l})\end{array}$ & $250-1000$ & 3 & 0.055 & 0.056 \\
\hline $\begin{array}{l}\mathrm{NO}_{3}{ }^{2-} \\
(\mathrm{mg} / \mathrm{l})\end{array}$ & $45-100$ & 2 & 0.036 & 0.178 \\
\hline $\begin{array}{l}\mathrm{Na}^{+} \\
(\mathrm{mg} / \mathrm{l})\end{array}$ & $20-200$ & 1 & 0.018 & 0.019 \\
\hline $\begin{array}{l}\mathrm{Fe}^{2+} \\
(\mathrm{mg} / \mathrm{l})\end{array}$ & $0.3-1.0$ & 6 & 0.109 & 0.019 \\
\hline Total alkalinity & $200-600$ & 7 & 0.127 & 0.185 \\
\hline Total hardness & $300-600$ & 8 & 0.145 & 0.093 \\
\hline Total & & 59 & 1 & 1 \\
\hline
\end{tabular}

Table 8 Water quality classification based on WQI value

\begin{tabular}{|c|c|c|c|c|c|}
\hline \multirow[t]{2}{*}{ WQI value } & \multirow[t]{2}{*}{ Rating of water quality } & \multicolumn{2}{|c|}{$\begin{array}{l}\text { Number of } \\
\text { samples }\end{array}$} & \multicolumn{2}{|c|}{$\begin{array}{l}\text { Percent- } \\
\text { age of } \\
\text { the water } \\
\text { samples }\end{array}$} \\
\hline & & PrM & PoM & PrM & PoM \\
\hline $0-25$ & Excellent water quality & 4 & 3 & $18 \%$ & $18 \%$ \\
\hline $26-50$ & Good water quality & 17 & 16 & $29 \%$ & $28 \%$ \\
\hline $51-75$ & Poor water quality & 1 & 3 & $53 \%$ & $54 \%$ \\
\hline $76-100$ & Very poor water quality & 0 & 0 & 00 & 00 \\
\hline Above 100 & $\begin{array}{l}\text { Unsuitable for drinking } \\
\text { purpose }\end{array}$ & 0 & 0 & 00 & 00 \\
\hline
\end{tabular}

where $q_{i}$ is the quality rating, $C_{i}$ is the concentration of each chemical parameter in each water sample in $\mathrm{mg} / \mathrm{l}$ and $S_{i}$ is the drinking water standard for each chemical parameter in $\mathrm{mg} / \mathrm{l}$ according to the guidelines of WHO (2017).

For determining the WQI, the SI is first determined for each parameter, by the following equation:

$\mathrm{SI}_{i}=W_{i} \times q_{i} ;$

$\mathrm{WQI}=\sum \mathrm{SI}_{i}$

$\mathrm{SI}_{\mathrm{i}}$ is the sub-index of $i$ th parameter, $q_{i}$ is the rating based on concentration of $i$ th parameter and $n$ is the number

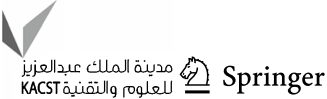


of parameters. The computed WQI values are classified into five types, "excellent water" to "water, unsuitable for drinking".

Table 7 represents the estimated relative weight of the chemical parameters of the groundwater for PrM and PoM. Table 8 shows the percentage of water samples of the block that falls under different class. Figure 13 shows the pi-chart classifications of studied water samples according to WQI; (a) during PrM; (b) during PoM.

\section{Schoeller diagram}

Schoeller (1977) diagram is delineated to classify the drinking water quality. The diagram is designed with the concentrations of most essential all major cations and anions as well as total hardness and total dissolved solids for drinking water quality classification (Sayad et al. 2011). Figure 14 presents the classification of the water samples into three zones, i.e. good, acceptable and unsuitable zones as stated by desirable and permissible limits of the parameter for drinking water (WHO 2017) according to Schoeller diagram. During PoM most of the water samples fall in the limits of 'good' and 'acceptable' zones, whereas during PoM most of samples proceed up in the 'unsuitable' zone.

\section{Conclusions}

The present study reveals a new set of updated data and physicochemical assessment of groundwater of Indur block, Bankura district, West Bengal, India. Water table depth of the block ranges from 9.9 to $4.9 \mathrm{~m}$ (bgl) during PrM and

(a) Pre-monsoon

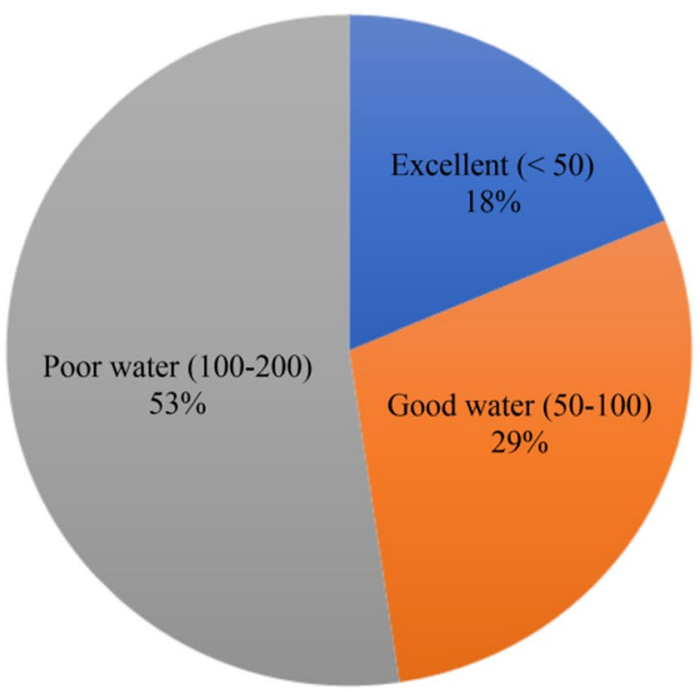

Pom, respectively. Maximum depth was noted 29.9 m during PrM at L1 and minimum of $3.0 \mathrm{~m}$ at L14 during Pom. Because of thin soil cover and near to surface occurrence of basement rock, subsurface water table head remains comparatively much higher at the $\mathrm{W}$ and $\mathrm{NW}$ side of the block. The overall direction of groundwater flow was from the $\mathrm{W}$ to SE with stagnancy at the south of the central location, and SE side of the block during PrM and PoM. The SE recharge zone expanded inward by a sizeable extent during PoM, whereas central recharge zone depleted considerably.

The $\mathrm{pH}$ of the water is close to the standard value and mean ranged between 6.5 and 6.7. TDS was comparatively lower at the locations of Western side of the block. Considerable increase in the TDS value was noted during PoM and this rise was drastically higher in the locations of central and eastern side of the block (L8; L10; L14; L16; L18; L19).

Chemical analysis reveals that the concentrations of $\mathrm{NO}_{3}{ }^{-}, \mathrm{Fe}^{2+}, \mathrm{HCO}_{3}{ }^{-}$and the values of $\mathrm{TH}$ were significantly higher than acceptable limits. During PrM, the mean concentration of $\mathrm{NO}_{3}{ }^{-}$was $17.3 \mathrm{mg} / \mathrm{l}$ and that rise $155.9 \mathrm{mg} / \mathrm{l}$ during PoM. The concentration of $\mathrm{Fe}^{2+}$ in the block water was drastically higher during PrM $(5.1 \mathrm{mg} / \mathrm{l})$ than PoM $(0.9 \mathrm{mg} / \mathrm{l})$. Increased leaching through the comparative thicker layers of residual lateritic soil cover after PoM is the crucial reason for the rapid increase of $\mathrm{Fe}^{2+}$ in PrM. Quick withdrawal of groundwater and use of fertilizers for irrigation were predominantly responsible for gradual degradation of the water quality considering the abnormal concentration of $\mathrm{NO}_{3}^{-}, \mathrm{Fe}^{2+}$.

Overall irrigation suitability of the groundwater rated as good except a few locations at NW of the block. SAR value ranges from 9.93 to 0.46 (during PrM and PoM,

(b) Post-monsoon

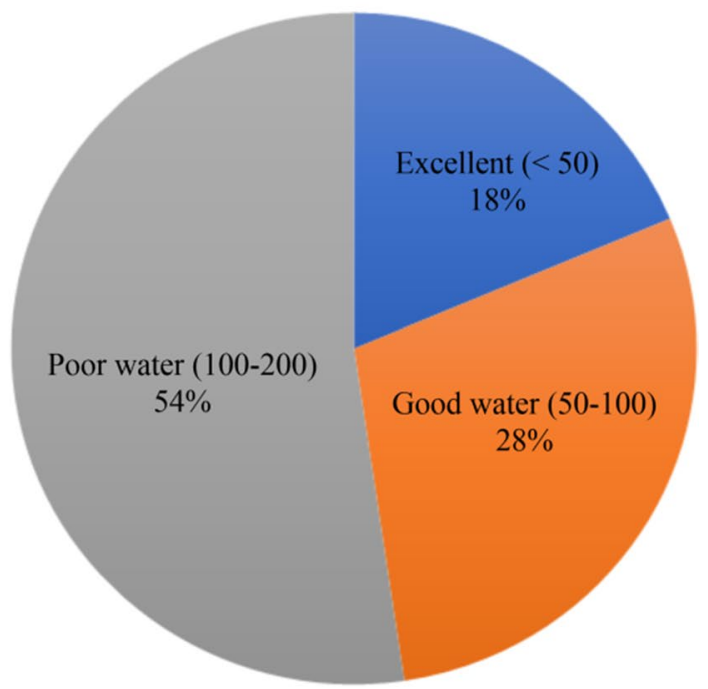

Fig. 13 Categorization of groundwater according to WQI; a PrM; b PoM 
Fig. 14 Schoeller diagram; a PrM; b PoM
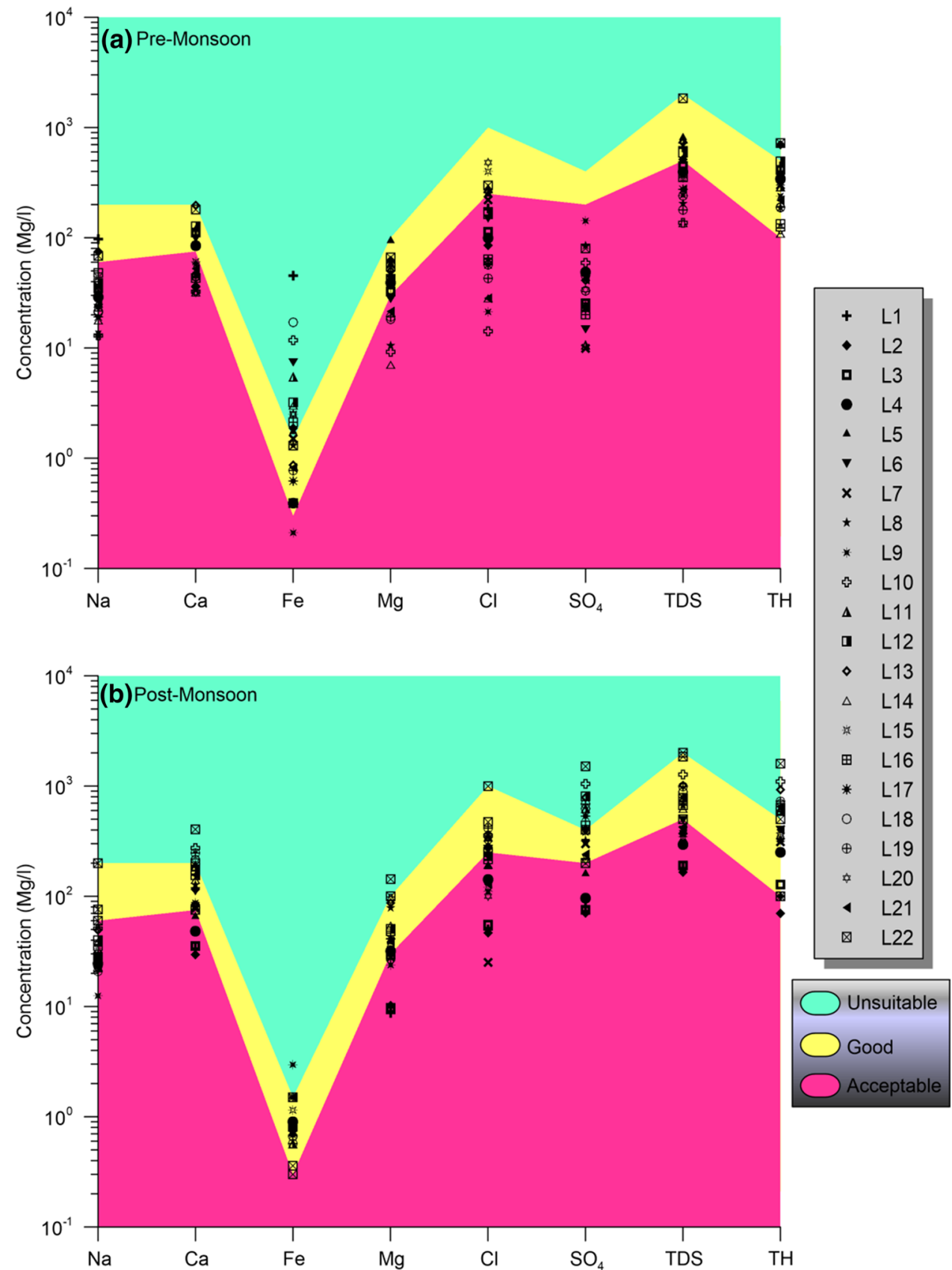

respectively) and reveals the water is well suitable for irrigation. Plots on US Salinity Diagram revealed that the water mostly falls in low sodium hazard zones and restricted at the basal-most portion of C1-S1, C2-S1 and C3-S1 classes. 'Wilcox Diagram' revealed that water grouped in "Very Good to Good" domain. Classification of water for its drinking suitability by 'Piper diagram' indicates that during PrM, nearly $40 \%$ of the samples falls within Calcium-Magnesium-Sulphate-Chloride facies while in PoM, nearly $68 \%$ of the samples belong to Calcium-Magnesium-Sulphate-Chloride facies (i.e. in sulphate region). Moreover, Water Quality Index and
Schoeller diagram indicate the quality of the water mostly in the good and acceptable zone during pre-monsoon, whereas during post-monsoon a substantial numbers of water samples range mainly in the unsuitable zone.

Acknowledgements This work has been carried out under the supervision of retired Professor Sisir K. Nag and Dr. Susanta Chaudhuri. The authors are highly thankful to the reviewers and editors for fruitful comments to improve the quality of the paper.

Authors contribution All authors contributed to field study, sample collection, data interpretation and literature search and in writing manuscript. All authors read and approved the final manuscript. 
Funding The research was funded and supported by JU-RUSA 2.0 Doctoral Scholarship scheme for Research Support to Faculty Members, Thrust Area-Sustainable Development, under RUSA 2.0-JU. Ref no. R-11/448/19, dated 30.05.2019.

\section{Declaration}

Conflict of interest The author(s) declare(s) that there is no conflict of interest regarding the publication of this paper.

Open Access This article is licensed under a Creative Commons Attribution 4.0 International License, which permits use, sharing, adaptation, distribution and reproduction in any medium or format, as long as you give appropriate credit to the original author(s) and the source, provide a link to the Creative Commons licence, and indicate if changes were made. The images or other third party material in this article are included in the article's Creative Commons licence, unless indicated otherwise in a credit line to the material. If material is not included in the article's Creative Commons licence and your intended use is not permitted by statutory regulation or exceeds the permitted use, you will need to obtain permission directly from the copyright holder. To view a copy of this licence, visit http://creativecommons.org/licenses/by/4.0/.

\section{References}

Abbasi T, Abbasi SA (2012) Water quality indices, 1st edn. Elsevier Acworth RI (1987) The development of crystalline basement aquifers in a tropical environment. Quat J Eng Geol 20:265-272

Alobaidy AJ, Abid H, Maulood KB (2010) Application of water quality index for assessment of Dokan lake ecosystem Kurdistan region, Iraq. J Water Resour Protect 2(09):792-798

Apambire WB, Boyle DR, Michael FA (1997) Geochemistry, genesis, and health implications of fluoriferous groundwaters in the upper regions of Ghana. Env Geol 33(1):13-24

APHA [American Public Health Association] (1995) Standard Methods for Examination of Water and Waste Water. American Public Health Association, American Water Works Association and Water Pollution Control Federation, Washington DC

Babiker IS, Mohamed AAM, Terao H, Kato K, Ohta K (2004) Assessment of groundwater contamination by nitrate leaching from intensive vegetable cultivation using geographical information system. Environ Int 29(8):1009-1017

Bureau of Indian Standard (2012) Drinking Water Specification, Second Revision, Bureau of Indian Standards, Manak Bhawan, 9, Bahadur Shah Zafar Marg, New Delhi

CGWB (2010) Groundwater quality in shallow aquifers of India. Central Ground water Board, Ministry of Water Resiources, Government of India, Faridabad

CGWD (2016) Technical Report-no. 278 series D, Groundwater Year Book of West Bengal \& Andaman \& Nikobar Island 2015-1016

CGWD (2015-2016). Ground Water Year Book of West Bengal \& Andaman \& Nicobar Island. https://bankura.gov.in/document/distr ict-gazetteer-new-chapter-i-physical-aspects_17-27

Chakrabarti S, Bhattacharya H (2013) Inferring the hydro-geochemistry of fluoride contamination in Bankura district, West Bengal: a case study. J Geol Soc India 82:379-391

Dewandel B, Lachassagne P, Wyns R, Maréchal JC, Krishnamurthy NS (2006) A generalized 3-D geological and hydrogeological conceptual model of granite aquifers controlled by single or multiphase weathering. Jour Hydrol 330(1-2):260-284

Domenico PA, Schwartz FW (1990) Physical and chemical hydrogeology. Wiley, New York, pp 410-420
Doneen LD (1964) Water quality for agriculture. Dept of irrigation, University of California, Davis

Freeze RA, Cherry JA (1979) Groundwater. Prentice-Hall, Inc., Englewood Cliffs, New Jersey, p 07632

Hem JD (1985) Study and Interpretation of the Chemical Characteristics of Natural Water (3rd edn). United States Geological Survey Water-Supply Paper 2254

Jeevanandam M, Kannan R, Srinivasalu S, Rammohan V (2006) Hydrogeochemistry and groundwater quality assessment of lower part of the Ponnaiyar River Basin, Cuddalore District, South India. Env Monit Assess 132(1-3):263-274

Karunakaran K, Thamilarasu P, Sharmila R (2009) Statistical study on physicochemical characteristics of groundwater in and around Namakkal, Tamilnadu. Ind J Chem 6(3):909-914

Kelly WP (1963) Use of saline irrigation water. Soil Sci 95(4):355-391

Kortatsi BK (2007) Hydrochemical framework of groundwater in the Ankobra Basin, Ghana. Aqua Geochem 13(1):41-74

Krishnamurthy J, Mani A, Jayaraman V, Manivel M (2000) Groundwater resources development in hard rock terrain-an approach using remote sensing and GIS techniques. Intl J Appl Earth Obs Geoinform 2(3-4):204-215

Kumar M, Kumari K, Ramanathan AL, Saxena R (2007) A comparative evaluation of groundwater suitability for irrigation and drinking purposes in two intensively cultivated districts of Punjab, India. Environ Geol 53:553-574

Laluraj CM, Gopinath G (2006) Assessment on seasonal variation of groundwater quality of phreatic aquifers - a river basin system. Environ Monit Assess 117:45-47

Lumb A, Sharma TC, Bibeault JF, Klawunn P (2011) A comparative study of USA and Canadian water quality index models. Water Quality, Exposure and Health 3:203-216

Mondal S, Kumar S (2017) Investigation of fluoride contamination and its mobility in groundwater of Simlapal block of Bankura district, West Bengal, India. Environ Earth Sci 76:778. https://doi.org/10. 1007/s12665-017-7122-7

Nag SK, Biswas S (2016) Groundwater quality and its suitability for irrigation and domestic purposes: a study in Rajnagar Block, Birbhum District, West Bengal, India. J Earth Sci Clim Change 7(2):337. https://doi.org/10.4172/2157-7617.1000337

Nag T, Ghosh A (2013) Cardiovascular disease risk factors in Asian Indian population: a systematic review. J Cardiovasc Dis Res 4(4):222-228

Nag SK, Lahiri A (2012) Hydrochemical characteristics of groundwater for domestic and irrigation purposes in Dwarakeswar Watershed area, India. Am J Clim Change 1:217-230

Nag SK, Ray S (2015) Hydrochemical evaluation of groundwater quality of Bankura I and II Blocks, Bankura District, West Bengal, India: emphasis on irrigation and domestic utility. Arab J Sci Eng 40:205-214

Nagarajan R, Rajmohan N, Mahendran U, Senthamilkumar S (2010) Evaluation of groundwater quality and its suitability for drinking and agricultural use in Thanjavur city, Tamil Nadu, India. Env Monitor Assess 171:289-308

Nas B, Berktay A (2006) Groundwater contamination by nitrates in the city of Konya, (Turkey): a GIS perspective. J Env Manage 79(1):30-37

Paliwal KV (1972) Irrigation with saline water. Monogram no. 2 (New series). New Delhi, IARI, 198

Palmajumder M, Chaudhuri S, Das VK, Nag SK (2020) Hydrogeochemistry and overall appraisal of groundwater status of Taldangra block, Bankura District, West Bengal, India. Asian J Water Env Pollut 17(4):37-46

Patil VT, Patil PR (2010) Physicochemical analysis of selected groundwater samples of Amalner Town in Jalgaon District, Maharashtra. Ind J Chem 7(1):111-116 
Piper AM (1944) A graphical procedure in the geochemical interpretation of water analysis. Trans Am Geophys Union 25:914-928

Prasanna MV, Chidambaram S, Gireesh TV, Ali TJ (2011) A study on hydrochemical characteristics of surface and sub-surface water in and around Perumal Lake, Cuddalore district, Tamil Nadu, South India. Environ Earth Sci 63(1):31-47

Raghunath IIM (1987) Groundwater, 2nd edn. Wiley Eastern Ltd., New Delhi, pp 344-369

Rajmohan N, Elango L (2005) Nutrient chemistry of groundwater in an intensively irrigated region of Southern India. Env Geol 47:820-830

Ramakrishnalah CR, Sadas Hivalah C, Ranganna G (2009) Assessment of water quality index for the groundwater in Tumkur Taluk, Karnataka state, India. E-J Chem 6(2):523-530

Reddi KR, Jayaraju N, Suriyakumar I, Sreenivas K (1993) Tidal fluctuation in relation to certain physico-chemical parameters in Swarnamukhi river estuary, East Coast of India. Indian J Mar Sci 22:223-234

Richards LA (1954) Diagnostics and improvement of saline and alkaline soils. U.S. Dept. of Agriculture hand book no. 60. U.S. Salinity Laboratory, Washington, DC

Rudra S, Khan U (2019) Geochemical evaluation of groundwater quality with respect to fluoride contamination at Simlapal Block of Bankura District, West Bengal. Themat J Geogr 8(4):527-539

Sajil Kumar PJ, Jegathambal P, James EJ (2014) Chemometric evaluation of nitrate contamination in the groundwater of a hard rock area in Dharapuram, south India. Appl Water Sci 4(4):397-405

Sawyer CN, Mccarty PL (1967) Chemistry for sanitary engineers (2nd edn). McGraw-Hill, New York, pp 518
Sayad N, Ditterich IRG, Pinto MHB, Wambier DS (2011) Concentraco de fluorem aguas minerais engarrafadas commercializadasno municipio de Ponta Grossa-PR. Rev Odontol UNESP 40:182-186

Scholler H (1977) Geochemistry of groundwater. Groundwater studies-an international guide for research and practice. UNESCO, Paris. pp 1-18

Shainberg I, Oster JD (1976) Quality of irrigation water. IIIC publication no. 2 Technical report-Series D; No.278 of CGWB 2015-16

Todd DK (1980) Ground water hydrology. Wiley, New York, p 527

Twari AK, Singh PK, Mahato MK (2016) Hydrogeochemical investigation and qualitative assessment of surface water resources in west Bokaro Coalfield, India. J Geol Soc India 87:85-96

Tyagi SK, Datta PS, Pruthi NK (2009) Hydrochemical appraisal of groundwater and its suitability in the intensive agricultural area of Muzaffar nagar district, Uttar Pradesh, India. Env Geol 56:901-912

US Salinity Lab (1954) Saline and Alkali Soils-Diagnosis and Improvement of US Salinity Laboratory; Agriculture Hand Book No. 60, Washington

Widory D, Kloppmann W, Chery L, Bonnin J, Rochdi H, Guinamant JL (2004) Nitrate in groundwater: an isotopic multi-tracer approach. J Contam Hydrol 1-4:165-168

Wilcox LV (1955) Classification and use of irrigation waters. USDA, Circular 969, Washington

World Health Organization, (2017) Guidelines for drinking-water quality, (4th edn). Incorporating first addendum 